NASA Technical Memorandum 89913

AIAA-87-9226

\title{
Fluoride Salts and Container Materials for Thermal Energy Storage Applications in the Temperature Range 973 to $1400 \mathrm{~K}$
}

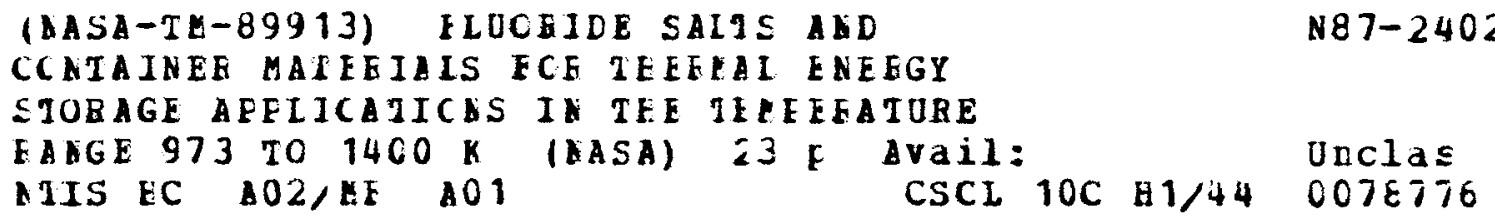

Ajay K. Misra and J. Daniel Whittenberger

Lewis Research Center

Cleveland, Ohio

Prepared for the

22nd Intersociety Energy Conversion Engineering Conference

cosponsored by the AIAA, ANS, ASME, SAE, IEEE, ACS, and AIChE Philadelphia, Pennsylvania, August 10-14, 1987 
FLUORIUE SALIS ANO CONIAINER MAIERIALS FOR THERMAL ENERGY SIORAGE

APPLICATIONS IN THE TEMPERATURE RANGE 973 TO $1400 \mathrm{~K}$

Ajay K. Misra* and J. Daniel Whittenberger

National Aeronatics and Space Administration

Lewis Research Center

Cleveland, Ohio 44135

\begin{abstract}
SUMMARY
Multicomponent fluoride salt mixtures were characterized for use as latent heat of fusion heat storage materials in advanced solar dynamic space power systems with operating temperatures in the range of 973 to $1400 \mathrm{~K}$. The melting points and eutectic compositions for many systems with published phase diagrams were verified, and several new eutectic compositions were identified. Additionaliy the heats of fusion of several binary and ternary eutectics and congruently melting intermediate compounds were measured by differential scanning calorimetry. The extent of corrosion of various metals by fluoride melts was estimated from thermodynamic considerations, and equilibrium conditions inside a containment vessel were calculated as functions of the initial moisture content of the salt and free volume above the molten salt. Preliminary experimental data on the corrosion of commercial, high-temperature alloys in $\mathrm{LIF}-19.5 \mathrm{CaF}_{2}$ and $\mathrm{NaF}-27 \mathrm{CaF}_{2}-36 \mathrm{MgF}_{2}$ melts are presented and compared to the thermodynamic predictions.
\end{abstract}

\title{
INTRODUCTION
}

Latent heat of fusion phase change materials are being considered for heat storage in advanced solar dynamic space power systems. In order to keep the total weight of the space power system to a minimum, the phase change material must have a high heat of fusion per unit mass. It is anticipated that heats of fusion greater than $0.4 \mathrm{~kJ} / \mathrm{g}$ would be needed. Also to minimize the weight of the container material, use of a phase change material with a high heat of fusion per unit melt volume would be desirable. Finally as current efforts are being focussed on Brayton and Stirling cycle heat engines with operating temperatures in the range of 973 to $1400 \mathrm{~K}$ (ref. 1), the melting point of the phase change material must lie within this temperature range.

There are only a few inorganic fluoride salts, i.e., NaF, KF, and LiF, which meet the melting point and heat of fusion requirements. These fluorides can be used only if the operating temperature of the heat engine is compatible with their melting points; this condition puts severe restrictions on the choice of the operating temperature for the heat engine. However, this limitation can be removed if fluoride based eutectic mixtures and/or congruently melting intermediate compounds are considered. Unfortunately little, other than compositions and melting points, is known about such systems, and in many cases the published phase diagrams are of questionable accuracy because the data determined by different authors are often in poor agreement. In addition

* Department of Metallurgy and Materials Science, Case Western Reserve University, Cleveland, Ohio 44106 and NASA Lewis Resident Research Associate. 
to the need for reliable thermochemical and thermophysical data, compatibility of the multicomponent fluoride salt systems with possible materials of construction must be studied to select a sultable containment vessel material.

This report describes the results of our studies on (1) characterization of multicomponent fluoride salt mixtures, and (2) corrosion of commercial, hightemperature alloys in several fluoride melts. The melting points and eutectic compositions for many systems with published phase diagrams were experimentally verified, and new eutectic compositions with melting points between 973 and $1400 \mathrm{~K}$ were identified. The heats of fusion of several binary and ternary eutectics and congruently melting intermediate compounds were experimentally measured by differential scanning calorimetry. Additionally thermodynamic calculations have been made to determine the probable extent of corrosion of metals in fluoride melts with and without the moisture in the system. Preliminary results on the corrosion of commercial, high-temperature alloys in fluoride melts will also be presented.

\section{THERMAL ANALYSIS AND HEAT OF FUSION MEASUREMENTS}

\section{Experimental Procedure}

Melting points and heats of fusion of salt mixtures were measured in a Perkins Elmer DTA 1700 instrument. Heat of fusion measurements were made by utilizing the instrument in the differential scanning calorimetry (DSC) mode. A detailed discussion of the salt purification steps and exact experimental procedures are reported elsewhere (ref. 2).

\section{Systems with Published Phase Diagrams}

Table I gives a summary of heat of fusion and melting point measurements for eutectic compositions and congruently melting intermediate compounds for salt systems with known phase diagrams. This table also contains the melting points and heats of fusion of pure fluoride salts for comparison. With the exception of eutectic compositions in the LiF-MgF 2 and $\mathrm{KF}-\mathrm{MgF}_{2}$ systems and the congruently melting intermediate compound $\mathrm{NaMgF}_{3}$ in $\mathrm{NaF}-\mathrm{MgF}_{2}$, there was close agreement (within $5 \mathrm{~K}$ ) between the measured and published melting points. The melting temperature for the intermediate compound $\mathrm{NaMgF}_{3}$ was found to be $8 \mathrm{~K}$ lower than that of Bergman et al. (ref. 7), and the melting point for $\mathrm{KF}-15 \mathrm{MgF}_{2}$ was $12 \mathrm{~K}$ higher than the pubilshed data of DeVries and Roy (ref. 8 ).

There appears to be considerable uncertainty in the published LiF-MgF 2 phase diagram. Bergman and Dergunov (ref. 7) investigated this system and found a complete series of solid solutions between Lif and $\mathrm{MgF}_{2}$ with a minimum melting point at about $33 \mathrm{~mol} \% \mathrm{MgF}_{2}$. The phase diagram data of Counts et al. (ref. 9) show extensive solid solubility on each side of the phase diagram with an eutectic at $36 \mathrm{~mol} \% \mathrm{MgF}_{2}$, although the existence of the eutectic was not conclusively established. Limited thermal analysis experiments by Roake (ref. 10) suggest the presence of an eutectic with a meiting temperature of $997 \mathrm{~K}$; unfortunately Roake's study was limited to only 15, 40, and $50 \mathrm{~mol}_{\%} \mathrm{MgF}_{2}$, and the exact eutectic composition was not determined. Because of poor agreement among the investigators of the Lif-MgF2 system, we have conducted in-depth thermal analysis experiments for LiF-MgF 2 mixtures in the range of 0 to $50 \mathrm{~mol} \times \mathrm{MgF}_{2}$. The thermal analysis data, shown in 
table Il, indicate an eutectic at about $30 \mathrm{~mol} * \mathrm{MgF}_{2}$ and with a melting temperature of $1001 \mathrm{~K}$.

Among the salt systems with published phase diagrams, there are only a few salt mixtures with very high heat of fusion per unit mass: Lif-19.5CaF 2 at $0.82 \mathrm{~kJ} / \mathrm{g}, \mathrm{NaF}-60 \mathrm{MgF} 2$ at $0.71 \mathrm{~kJ} / \mathrm{g}, \mathrm{KF}-69 \mathrm{MgF}_{2}$ at $0.77 \mathrm{~kJ} / \mathrm{g}$ and $\mathrm{KMgF}_{3}$ at $0.71 \mathrm{~kJ} / \mathrm{g}$. As shown in table $\mathrm{I}$, all the above salts are also likely to have high heat of fusion per unit liquid volume. Additionally Lif-20CeF 3 seems to be a suitable candidate if high heat of fusion per unit liquid volume is required, even though it has a relatively low heat of fusion per unit mass $(0.5 \mathrm{~kJ} / \mathrm{g})$. This is due to the higher liquid density $\left(\sim 4.63 \mathrm{~g} / \mathrm{cm}^{3}\right)$ for $\mathrm{CeF}_{3}$ (ref. 6) as compared to the alkali fluoride melts $\left(\sim 1.8\right.$ and $\sim 1.8 \mathrm{~g} / \mathrm{cm}^{3}$ for Lif and NaF melts respectively) (ref. 5).

\section{Identification of New Eutectic Compositions}

Since Lif has a very high heat of fusion per unit mass $(1.08 \mathrm{~kJ} / \mathrm{g})$, it is anticipated that an eutectic between Lif and another compound would also have a reasonably high heat of fusion per unit mass provided there is no extensive solid solution between the two. The heat of fusion measurements (table I) show that the intermediate compounds $\mathrm{NaMgF}_{3}$ and $\mathrm{KMgF}_{3}$ have very high heat of fusion per unit mass $(0.67$ and $0.71 \mathrm{~kJ} / \mathrm{g}$, respectively); therefore, examination of $\mathrm{mix}$ tures of these intermediate compounds and Lif could reveal useful phase change salts. To identify possible eutectic compositions in these systems, the partial phase diagrams for the two quasi-binary systems have been determined by differential thermal analysis. As can be seen in figures 1 and 2 both LiF-NaMgF 3 and LiF-KMgF 3 have eutectics with extremely limited or no solid solubility within the composition ranges investigated.

$\mathrm{MgF}_{2}$ also has a very high heat of fusion per unit mass and a high melting point; therefore it is of interest to identify potential Mgf 2 -base systems, particularly, for higher temperature $(1300$ to $1400 \mathrm{~K})$ applications. The partial phase diagram for one $\mathrm{MgF}_{2}$-base system, $\mathrm{MgF}_{2}-\mathrm{CeF}_{3}$, has been determined, and it has an eutectic at $1393 \mathrm{~K}$ with no solid solutions (fig. 3 ).

Table III lists the melting points and heats of fusion for the three newly identified eutectic compositions. The eutectic for the quasi-binary $\mathrm{LiF}-\mathrm{KMgF}_{3}$ system has a very high heat of fusion per unit mass $(0.86 \mathrm{~kJ} / \mathrm{g})$ and thus would be attractive for space power applications. Even though it has a low heat of fusion per unit mass, the $\mathrm{MgF}_{2} \mathrm{CeF}_{3}$ eutectic might be attractive on a volume basis.

\section{Problem of Undercooling}

Undercooling was observed in many systems, and table IV shows the extent for pure salts and mixtures. Because of considerable scatter in undercooling for different runs of the same sample, a range of values for the extent of undercooling is shown in table IV. The reported undercoolings are for very small sample sizes and high purity materials normally used in the thermal analysis experiments. Since small, high purity samples tend to undercool more than large, less pure materlals, the degree of undercooling is expected to be lower in actual service conditions. Thus for many salt systems where the undercooling is $20 \mathrm{~K}$ or less, there might not be any practical problems. However when 
the intermediate compound $\mathrm{NaMgF}_{3}$ was formed, the underccoling was considerable $(>30 \mathrm{~K})$, and it could be a serious problem in actual service conditions if Naf $\mathrm{MgF}_{2}$-based systems are used.

\section{THERMODYNAMIC CONSIDERATIONS FOR CORROSION OF METALS IN THERMAL ENERGY STORAGE SYSTEMS}

A schematic of a thermal energy salt container is shown in figure 4 . It has been partially filled and then sealed by welding in either an inert atmosphere or a vacuum. The salt-filled container is placed in a heat transfer fluid, which during the sunlit portion of each orbi (about $1 \mathrm{hr}$ ) provides the energy to melt the salt. The heat stored in the phase change material is then extracted by the same heat transfer fluid during the eclipse portion of each orbit $(\sim 1 / 2 \mathrm{hr})$, as the salt solidifies. Since the atmosphere above the salt is initialiy inert, the primary mode of attack is expected to be direct reaction of the metals with the salt melt. However, additional modes of degradation could be introduced if the salt contains impurities such as water. In the following, thermodynamic calculations are presented to define the equilibrium conditions for possible corrosion reactions. For a given set of conditions, the equilibrium state represents the maximum extent of corrosion; therefore it would play an important role in assessing the long-term life of a containment material.

\section{Methodology of Calculations}

The equilibrium calculations were performed between 1000 and $1300 \mathrm{~K}$ by utilizing the concept of "extent of reaction" (refs. 11 and 12) and for one mole of salt in the container. For temperatures below the melting points of the salts, the Gibbs standard free energy for liquid fluorides were computed by standard thermodynamic procedures (ref. 13) utilizing the heat of fusion data at the melting point and the heat capacity as a function of temperature for both the liquid and solid states. Wherever possible the thermodynamic data were taken from Barin and Knacke's compilations (ref. 3 ); however the thermodynamic properties for several liquid fluorides (1.e., $\mathrm{CrF}_{2}, \mathrm{CrF}_{3}, \mathrm{NiF}_{2}, \mathrm{FeF}_{2}$, and $\left(\mathrm{CoF}_{2}\right)$ are not known and had to be estimated. While the main features of the calculations are given; the detailed descriptions are elsewhere (ref. 14).

\section{Reaction of $\mathrm{Fe}, \mathrm{N}\}, \mathrm{Co}, \mathrm{Cr}$, and $\mathrm{Al}$ with Fluoride Melts in an Inert Atmosphere}

In the absence of an oxidizing atmosphere, corrosion of a pure metal Me (Me $=\mathrm{Fe}, \mathrm{Ni}, \mathrm{Co}, \mathrm{Cr}$, or $\mathrm{Al}$ ) in an alkali fluoride (MF, M $=\mathrm{Li}, \mathrm{Na}$, or $\mathrm{K}$ ) melt would occur by the reaction

$$
x \operatorname{Me}(s)+y \operatorname{MF}(1)=\underline{\operatorname{Me}_{x} F_{y}(1)}+\underline{M(1)}
$$

where the underlining denotes that the species are present at reduced activity. For $\mathrm{N} 1, \mathrm{Co}, \mathrm{Fe}$, and $\mathrm{Cr}$ the relevant $\mathrm{Me}_{x} \mathrm{~F}_{y}$ compounds are $\mathrm{NiF}_{2}, \mathrm{CoF}_{2}, \mathrm{FeF}_{2}$, $\mathrm{CrF}_{2} / \mathrm{CrF}_{3}$, respectively. Although the reaction of $\mathrm{Al}$ with $\mathrm{MF}$ would result in formation of $\mathrm{AlF}_{3}$, the heat of mixing data for $M F-A l F_{3}$ melts (ref. 15) suggest the existence of complex species $A l F_{6}^{3-}$ which is equivalent to the formation of 
$\mathrm{M}_{3} \mathrm{All} \mathrm{F}_{6}$ by the reaction of $\mathrm{MF}$ and $\mathrm{AlF}_{3}$. Therefore the reaction of $\mathrm{Al}$ with the MF melts can be written as

$$
6 \operatorname{MF}(1)+A 1(5)=M_{3} A 1 F_{6}(1)+3 M(1)
$$

The equilibrium content of $\mathrm{Me}_{x} \mathrm{~F}_{y}$ (for $\mathrm{Ni}, \mathrm{Co}, \mathrm{Fe}, \mathrm{Cr}$ ) and $\mathrm{M}_{3} \mathrm{AlF}_{6}$ in the melt determines the maximum extent of corrosion, and the purpose of thermodynamic calculations is to estimate these concentrations.

Figure 5 shows the calculated equilibrium concentrations of various metal fluorides in alkall fluoride melts at $1100 \mathrm{~K}$ for corrosion of the pure metals under an inert atmosphere where ideal solution behavior was assumed for the melt. In all three systems the tendency for metals to corrode increases in the order: $\mathrm{Ni}, \mathrm{Co}, \mathrm{Fe}, \mathrm{Cr}, \mathrm{Al}$. The equilibrium concentration of $\mathrm{M}_{3} \mathrm{AlF} \mathrm{F}_{6}$ in the molten salts is so high that alloys containing significant amounts of Al are expected to suffer severe corrosion. Even though these calculations were performed for unit activity, the same conclusion would still hold when Al is present at a reduced activity. For example, taking the activity of $\mathrm{Al}$ in $\mathrm{Ni}_{3} \mathrm{Al}$ (the strengthening phase in $\mathrm{Ni}$-base superalloys) to be on the order of $10^{-5}$ (ref. 16), the equilibrium concentrations for $A 1$ in Lif and NaF melts at $1100 \mathrm{~K}$ would be 41 and $7360 \mathrm{~mol} \mathrm{ppm}$, respectively. Although these Al concentrations are lower than those for unit activity, they are sufficient to cause major corrosion of Al-containing alloys.

From figure 5 it can be seen that Lif is the least corrosive salt while NaF and KF are about equal in their attack. The equilibrium concentration of $\mathrm{Ni}, \mathrm{Co}, \mathrm{Fe}$, and $\mathrm{Cr}$ fluorides in a Lif melt are quite small ( $<1$ mol ppm); thus alloys containing these elements are expected to be corrosion resistant. Ni, $\mathrm{Fe}$, and $\mathrm{Co}_{0}$ are also anticipated to be free from damage in NaF and $\mathrm{KF}$ melts; on the other hand, alloys containing $\mathrm{Cr}$ might be corroded by these two melts because of higher solubility of $\mathrm{Cr}$ in the form of $\mathrm{CrF}_{2}$ (for example, $12 \mathrm{~mol} \mathrm{ppm}$ for $\mathrm{CrF}_{2}$ as compared to approximately $0.1 \mathrm{~mol} \mathrm{ppm}$ for $\mathrm{FeF}_{2}$ ). It appears that the formation of $\mathrm{CrF}_{3}$ is not important for corrosion of $\mathrm{Cr}$ due to its much lower solubility (about 2 orders of magnitude lower than that as $\left.\mathrm{CrF}_{2}\right)$.

The equilibrium concentrations of different metal fluorides in figure 5 were calculated under the assumption of ideal solution behavior in the melt, that is, the activity coefficient $(Y)$ of $M_{x} F_{y}$ in the melt was assumed to be unity. Although activity coefficients for Mexfy in alkali fluoride melts have not been measured; in systems for which phase diagrams are aval1able, they can be estimated from an analysis of the phase diagrams (ref. 17) and are shown in table $V$. As the activity coefficients are considerably less than unity, a strong negative interaction seems to exist in all the $M F-M e_{x} F_{y}$ type melts. In view of the estimates in table $v$, the activity coefficient of $\mathrm{Me}_{x} \mathrm{~F}_{y}$ for systems without phase diagrams (a $11 \mathrm{LiF}-\mathrm{Me}_{x} \mathrm{~F}_{y}$ systems and NaF-CrF ) will be assumed to be 0.001 in the following equilibrium calculations.

The effect of the nonideality and temperature on the equilibrium concentration of Mex $F_{y}$ in a LiF melt is shown in figure 6. Compared to the ideal solution behavior ( $f$ ig. 5), there is an order of magnitude increase in the concentration of $\mathrm{Me}_{\mathrm{x}} \mathrm{F}_{\mathrm{y}}$ at $1100 \mathrm{~K}$; even with such an increase, the equilibrium concentration of $\mathrm{N}_{2} \mathrm{~F}_{2}$ is still less than $0.01 \mathrm{~mol} \mathrm{ppm}$. Over the 1000 to $1200 \mathrm{~K}$ temperature range shown in this figure, the amounts of MexFy in the molten salts would increase about one order of magnitude. It is anticipated 
that the corrosion of $\mathrm{Fe}$ and $\mathrm{N} 1$ would be minimal because of the low concentrations of $\mathrm{FeF}_{2}$ and $\mathrm{NiF}_{2}$; on the other hand, the equilibrium concentration of $\mathrm{CrF}_{2}$ at $1200 \mathrm{~K}(14 \mathrm{~mol} \mathrm{ppm})$ is probably sufficient to casse some attack of $\mathrm{Cr}$ containing alloys at this temperature.

Figure 7 shows the equilibrium Me $\mathrm{F}_{y}$ concentrations between 1100 and $1300 \mathrm{~K}$ in a NaF melt utllizing the estimated activity coefficients for Me $\mathrm{F}_{y}$. Since the equilibrium concentration of $\mathrm{NiF}_{2}$ is very low, $\mathrm{Ni}$ is expected to be corrosion resistant. On the other hand, Fe will probably suffer from significant corrosion, particularly at higher temperatures, as the final concentrations of $\mathrm{FeF}_{2}$ in a NaF melt at 1200 and $1300 \mathrm{~K}$ were estimated to be 25 and $73 \mathrm{~mol} \mathrm{ppm}$, respectively. Additionally the equilibrium concentrations of $\mathrm{CrF}_{2}$ were computed to be $100 \mathrm{~mol} \mathrm{ppm}$ for $1100 \mathrm{~K}$ and $900 \mathrm{~mol} \mathrm{ppm}$ for $1300 \mathrm{~K}$; thus Cr-containing alloys might not be suitable for Naf-containing melts.

Corrosion of a metal Me in $\mathrm{MgF}_{2}$ or $\mathrm{CaF}_{2}$ melt can be written as

$$
x \operatorname{Me}(s)+y \mathrm{AF}_{2}(1)=\operatorname{Me}_{x} F_{y}(1)+y A(1)
$$

where $\mathrm{A}$ represents either $\mathrm{Ca}$ or $\mathrm{Mg}$. Calculation of the equilibrium concentration of $\mathrm{NiF}_{2}$ and $\mathrm{CrF}_{2}$ in a hypothetical $\mathrm{MgF}_{2}$ melt at $1100 \mathrm{~K}$ with the assumption of ideal solution behavior in the me1t yields $1.9 \times 10^{-5} \mathrm{~mol} \mathrm{ppm}$ for $\mathrm{NiF}_{2}$ and $0.08 \mathrm{~mol} \mathrm{ppm}$ for $\mathrm{CrF}_{2}$. These values are three orders of magnitude lower than those determined for corrosion in a NaF melt at $1100 \mathrm{~K}$ (fig. 5). Due to the greater thermodynamic stability of $\mathrm{CaF}_{2}$, the extent of corrosion in a $\mathrm{CaF}_{2}$ melt should even be lower than that in the $\mathrm{MgF}_{2}$.

\section{Reaction of Refractory Metals $\mathrm{Nb}$, Mo, W With Fluoride Melts Under an Inert Atmosphere}

There are no known condensed Nb, Mo, or $W$ fluorides between 1000 and $1400 \mathrm{~K}$; instead gaseous refractory fluorides are the stable phases. Consequently, the reaction of a refractory metal Me (Me $=\mathrm{Nb}$, Mo, or $W$ ) with an alkali fluoride MF can be written as

$$
x \operatorname{Me}(s)+y \operatorname{MF}(1)=\operatorname{Me}_{x} F_{y}(g)+y \underline{M(1)}
$$

Since a gas phase is involved in equation (4), for a closed system the extent of the reaction would be a function of the empty space available inside a container. Therefore all the calculations were performed as a function of a dimensionless variable $L$ which is defined as the ratio of the container volume to the molar volume of the salt melt. Table vI shows the amount of gaseous refractory metal formed per mole of $\mathrm{NaF}$. The extent of reaction is quite small $\left(<10^{-7}\right.$ mol of metal consumed per mole of the salt) for all the refractory metals; therefore no significant corrosion of refractory metals in NaF is expected. While corrosion in KF will be very similar to that in NaF melts, due to the greater thermodynamic stablitity of Lif, refractory metals should be even less prone to attack in Lif than in NaF or KF. 


\section{Role of Moisture in Corrosion}

Water is a common impurity in the halide salts, and it has proven difficult to remove from fluorides (ref. 18). Unfortunately, the reaction of alkali fluorides with moisture generates gaseous $\mathrm{HF}$ by

$$
\begin{aligned}
& \mathrm{MF}(1)+\mathrm{H}_{2} \mathrm{O}(\mathrm{g})=\mathrm{MOH}(1)+\mathrm{HF}(\mathrm{g}) \\
& 2 \mathrm{MF}(1)+\mathrm{H}_{2} \mathrm{O}(\mathrm{g})=\mathrm{M}_{2} \mathrm{O}(1)+2 \mathrm{HF}(\mathrm{g})
\end{aligned}
$$

Part of the HF gas will then dissolve in the melt by the reaction

$$
H F(g)=\underline{H F(1)}
$$

The simultaneous equilibria and mass balance constraints for reactions (eqs. (5) to (7)) were used to determine the partial pressures of $\mathrm{HF}$ and $\mathrm{H}_{2} \mathrm{O}$ ( $P_{H F}$ and $P_{H O}$ ) above the melt, the total pressure in the container $\left(P_{T}\right)$, and mole fraction of dissolved $H F$ in the melt $\left(X_{H F}(M)\right)$ as functions of the initial moisture content in the salt and $L$ ratios. Results of these calculations for $\mathrm{NaF}$ melts at $1100 \mathrm{~K}$ and an initlal total pressure of 0.001 atm are shown in figures 8 and 9 . The gas pressures generated inside the container are strongly dependent on the initial moisture content irrespective of the free volume. On the other hand $L$ is only an important variable when moisture levels exceed $100 \mathrm{ppm}$. From figure $8(\mathrm{~d})$ it is clear that pressures greater than 1 atm can be generated for high water contents and small volumes. WHile such pressures could lead to mechanical fallure of the containment vessel, they would not be generated if the initial moisture levels are controlled to $100 \mathrm{~mol} \mathrm{ppm}$ or less.

In addition to pressurizing the containment vessel, the presence of moisture in the salt generates HF. Thus corrosion would take place both in the melt, as aided by the dissolved $\mathrm{HF}$, and in the free volume via attack from gaseous water and hydrogen fluoride. Figure 9 lllustrates that the concentration of dissolved HF for $100 \mathrm{~mol} \mathrm{ppm}$ of initial moisture in the salt is on the order of $10^{-4}$ mol per mole of NaF. If dissolved HF reacts with the metal containment vessel, serious corrosion problems could be anticipated. Furthermore, generation of $\mathrm{H}_{2}$ gas by the corrosion reaction

$$
x \mathrm{Me}+\mathrm{y} H \mathrm{HF}=\mathrm{Me}_{x} \mathrm{~F} y+\frac{y}{2} \mathrm{H}_{2}
$$

will increase the total pressure inside the container. Thermodynamic calculations for $L$ equal to 1.1 and with the assumption that all the dissolved HF reacts to form $\mathrm{H}_{2}$ gas demonstrate (fig. 10) that the total pressure inside the container will exceed $1 \mathrm{~atm}$ at a lower initial moisture content ( $40 \mathrm{~mol} \mathrm{ppm}$ ) compared to the case where there is no reaction between dissolved HF and the container material $(\sim 250 \mathrm{~mol} \mathrm{ppm})$.

From the thermodynamic analysis it is clear that the moisture content in Naf-based salts should be reduced to low levels, probably $10 \mathrm{~mol} \mathrm{ppm}$ or less, for prolonged container life. A similar conclusion can also be made Lif- and KF-based salt systems. 


\section{CORROSION EXPERIMENTS}

As part of the work in support of an advanced solar dynamic power system, corrosion studies in potential fluoride energy storage salts are being undertaken. Because of the large body of fabrication, joining and mechanical and physical property information which will eventually be required to build a heat receiver/storage unit, this effort is basicaliy being limited to commercialiy avallable, high temperature sheet alloys; although in view of forementioned thermodynamic factors, such alloys which generally contain $\mathrm{Al}$ and/or $\mathrm{Cr}$ for oxidation resistance are probably not the best choice.

In brief about $30 \mathrm{Co-}$, Fe-, Ni-base and refractory alloys (table VII) have been exposed to several eutectic salt mixtures (Lif-19.5CaF 2 which melts at $1039 \mathrm{~K}$ and $\mathrm{NaF}-27 \mathrm{CaF}_{2}-36 \mathrm{MgF}_{2}$ which melts at $1178 \mathrm{~K}$ ) at $T_{M}+25 \mathrm{~K}$ where $T_{M}$ is the eutectic melting point. Each experiment involved a metaliic specimen in contact with molten salt in a sealed, evacuated quartz capsule and/or open 2? umina crucible under an argon atmosphere for times ranging from 50 to $500 \mathrm{hr}$. Because residual water in the salt was deemed to be detrimental, the salts were heated under vacuum prior to sealing $\left(\mathrm{SHO}_{2}\right.$ capsule) or introduction of the argon $\left(\mathrm{Al}_{2} \mathrm{O}_{3}\right.$ crucible) to drive off excess $\mathrm{H}_{2} \mathrm{O}$. Upon completion of the exposure, the alloy samples were examined for evidence of corrosion by metallographic techniques.

Typical photomicrographs 11 lustrating the types of microstructural damage are presented in figure 11. The least noxious is a general attack consisting of smal1, Isolated near surface pores (fig.11(a); however it is apparent that general attack can produce interconnected porosity which becomes infiltrated with salt and leads to the stripping away of layers of metal (fig. 11(b)). Intergranular corrosion, as shown in figure $11(\mathrm{c})$, is usually a more severe form of damage with deep penetration into the alloy. Lastiy metals which are heavily corroded exhibit both general and intergranular effects (fig. 11(d)). In any case as the proposed iife for the advanced solar dynamic system is 7 years or more, any signs of attack, elther general or intergranular, would severely limit the usefulness of the alloy.

Because it was noted in other work (ref. 19) that the salts attacked the quartz capsules during the corrosion exposures, there was concern that the reactions among fluorides and $\mathrm{SiO}_{2}$ biased the results. The data in figure 12 , which compares the depth of corrosive attack for several alloys exposed to $\mathrm{NaF}-27 \mathrm{CaF}_{2}-36 \mathrm{MgF}_{2}$ in quartz capsules and alumina crucibles, reveals that the behavior and ranking is similar for both experimental techniques. However the extent of internal penetration is much greater for the alloys sealed in quartz, and it is most likely due to the combined effects of $\mathrm{H}_{2}$ and $\mathrm{SiO}_{2}$ reacting with the fluorides to form $\mathrm{SiO}_{2}$ compounds. Additionaliy evidence that the presence of quartz by itself does not greatly affect the degree of attack in $\mathrm{NaF}-27 \mathrm{CaF}_{2}-36 \mathrm{MgF}_{2}$ is presented in table VIII. In this case there is generally no difference (for example 304,347 , and Hastelloy-X) or very little deviation $(310,316 \mathrm{mild}$ steel, Hastelloy- N, Ni, and Ta) between the microstructural damage found in test samples after $100 \mathrm{hr}$ exposures in the molten eutectic adulterated or not adulterated with $\mathrm{SiO}_{2}$.

A listing of the depth of both general and intergranular corrosive attack for the tests conducted in alumina cructbles is given in table VIII. It should be noted that most of the $\mathrm{LiF}-19.5 \mathrm{CaF}_{2}$ leaked out of the $\mathrm{Al}_{2} \mathrm{O}_{3}$ crucibles during the $500 \mathrm{hr}$ heat treatments: however as the degree of corrosion for these tests 
scales with the $100 \mathrm{hr}$ results (no loss of salt observed), the long term data is probably valid. Since the alloying elements in the high-temperature materials do not vary in a systematic manner, it is difficult to make overall statements about behavior, and only one distinct trend was found. For Ni-base alloys immersed in the molten LiF-19.5 CaF 2 eutectic, the extent of attack generally increased with $\mathrm{Cr}$ content (fig. 13). A similar dependency was not observed in the $\mathrm{Cr}$ containing Fe-base alloys where the depth of corrosion for such alloys, which have between 16 and 27 percent $\mathrm{Cr}$, was about 40 and $150 \mu \mathrm{m}$ after 100 and $500 \mathrm{hr}$ heat treatments respectively. Additionally the Co-based materials were corroded by the $\mathrm{LiF}-19.5 \mathrm{CaF}_{2}$ mixture with damage extending to $\sim 100 \mu \mathrm{m}$ after $500 \mathrm{hr}$ of exposure. Based on the present results for the nonrefractory materials, only pure $\mathrm{Ni}$ appears to have sufficient corrosion resistance for long term use with LiF-19.5 $\mathrm{CaF}_{2}$. The alloy Hastelloy $B$ (consisting of $\mathrm{Ni}$, Mo, and $\mathrm{Fe}$ ) might also be suitable in this salt melt.

The data for specimens which had been subjected to $\mathrm{NaF}-27 \mathrm{CaF}_{2}-36 \mathrm{MgF}_{2}$ at $1203 \mathrm{~K}$ (table VIII) fell into three groups:

(1) The pure metals Mo and $W$ and the alloys Hastelloy $B$ and $\mathrm{Nb}-1 \mathrm{Zr}$ appear to have undergone very little, if any, attack.

(2) The ferritic alloy $18 \mathrm{~S} / \mathrm{R}$, Hastelloy $\mathrm{X}, 800$ and pure Ta exhibited damage zones of about $40 \mu \mathrm{m}$.

(3) All the remaining $\mathrm{CO}-$, Fe-, and $\mathrm{Ni}$-base alloys experienced $\sim 10 \mu \mathrm{m}$ deep corrosion.

In view of previous work with three other NaF-based eutectics (ref. 19), it is not clear why the $\mathrm{Ni}$-base alloys Hastelloy $X$ and 800 were more severely attacked than the other nickel-rich materials, or why pure $\mathrm{Ni}$ and $\mathrm{Fe}$ experienced some corrosion.

While the thermodynamic calculations (fig. 6) indicated that Cr-containing alloys should not be subject to attack in Lif-based melts, the data in table VIII and figure 13 show that this is not tne case for the present experiments in Lif-19.5 $\mathrm{CaF}_{2}$. Most likely this behavior is a result of either the included moisture which was not removed by the vacuum anneal prior to the corrosion exposures or the moisture $(\sim 200 \mathrm{ppm})$ present in the argon gas; additionally it is possible that reactions between this eutectic and alumina cruct. bles ylelded chemical species which tended to increase the corrosivity of the molten salt. Comparison of the data from the ternary NaF system (table VIII) with the thermodynamic predictions (fig. 7) reveals that they are basically in agreement. The refractory metals $\mathrm{Nb}, \mathrm{Mo}$, and $W$ and the $\mathrm{N} i$-Mo alloy Hastelloy $B$ were not harmed, while the alloys with $\mathrm{Cr}$ experienced some microstructural damage.

\section{SUMMARY OF RESULTS}

Multicomponent fluoride salt mixtures, suitable for use as latent heat of fusion heat storage materials in advanced solar dynamic space power systems with operating temperatures in the range of 973 to $1400 \mathrm{~K}$, were characterized via thermodynamic calculations and measurements and corrosion experiments. Several new eutectic compositions were identified in LiF-NaF-MgF 2 , LiF-KF-MgF 2 , and $\mathrm{MgF}_{2}-\mathrm{CeF}_{3}$, and the melting points and eutectic compositions for many other 
fluoride base systems with published phase diagrams (for example Lif-19.5CaF 2 , $\mathrm{NaF}-23 \mathrm{MgF}_{2}$, etc.) were experimentally verified. The heats of fusion and extent of undercooling for a number of binary and ternary eutectics and congruently melting intermediate compounds were established by differential scanning calorimetry and differential thermal analysis, and undercooling was found to be significant for systems which form $\mathrm{NaMgF}_{3}$.

Thermodynamic calculations were undertaken to estimate the corrosivity of molten fluoride salts in the absence of water. Similar determinations in addition to an evaluation of the internal pressure were made for sealed, salt filled containment vessels as functions of the initial moisture content and free volume above the melt. Such analyses clearly indicate that all fluorides must be essentialiy free of all included $\mathrm{H}_{2} \mathrm{O}(<10 \mathrm{~mol} \mathrm{ppm})$ to prevent attack of common alloys. The results of corrosion experiments involving a large number of commercial, high-temperature alloys in LiF-19.5CaF 2 at $1070 \mathrm{~K}$ and $\mathrm{NaF}-27 \mathrm{CaF}_{2}-36 \mathrm{MgF}_{2}$ at $1203 \mathrm{~K}$ are given and compared to the thermodynamic predictions.

\section{REFERENCES}

1. Juhasz, A.J., Coles-Hamilton, C.E., and Lacy, D.E., "Impact of Thermal Energy Storage Properties on Solar Dynamic Power Conversion System Mass," NASA TM-89909, 1987. (to be presented at the 22nd IECEC).

2. Misra, A.K., "Fluoride Salts as Phase Change Materials for Thermal Energy Storage in the Temperature Range $1000^{\circ}-1400^{\circ} \mathrm{K}$," submitted for publication in the Journal of the Electrochemical Society.

3. Barin, I. and Knacke, 0., Thermochemical Properties of Inorganic Substances, Springer-Verlag, New York, 1973.

4. Janz, G.J., Gardner, G.L., Krebs, U., and Tomkins, R.P.T., "Molten Salts: Volume 4, Part 1, Fluorides and Mixtures. Electrical Conductance, Density, Viscosity, and Surface Tension Data," Journal of Physical and Chemical Reference Data, Vol. 3, No. 1, 1974, pp. 1-115.

5. Janz, G.J., Allen, C.B., Bansal, N.P., Murphy, R.M., and Tomkins, R.P.T., Physical Properties Data Compilations Relevant to Energy Storage, II. Molten Salts: Data of Single and Mult1-Component Salt Systems, National Bureau of Standards, Washington D.C., NSRDS-NBS-61-PT-2, 1979.

6. Kirschenbaum, A.D., Cah111, J.A., and Stokes, C.S., "The Density of Molten Metal Fluorides in the Range of $1600^{\circ}-2500^{\circ} \mathrm{K}$, " Journal of Inorganic and Nuclear Chemistry, Vol. 15, Nos. 3/4, 1960, pp. 297-304.

7. Bergman, A.G. and Dergunov, E.P., "Fusion Diagram of the System LiF-NaF-MgF 2 ," Comptes Rendus de l'Academie des Sciences de l'URSS (Dok lady Akademí Nauk SSSR). Vo1. 31, 1941, pp. 755-756.

8. DeVries, R.C. and Roy, R., "Fluoride Models for Oxide Systems of Dielectric Interest. The Systems $\mathrm{KF}-\mathrm{MgF}_{2}$ and $\mathrm{AgF}-\mathrm{ZnF}_{2}$, "Journal of the American Chemical Soctety, Vol. 75, No. 10, May 20, 1953, pp. 2479-2484. 
9. Counts, W.E., Roy, R., and Osborn, E.F., "Fluoride Model Systems: II, The Binary Systems $\mathrm{CaF}_{2}-\mathrm{BeF}_{2}, \mathrm{MgF}_{2}-\mathrm{BeF} 2$, and $\mathrm{LIF}-\mathrm{MgF}_{2}$," Journal of the American Ceramic Soctety, Vol. 36, No. 1, Jan. 1953, pp. 12-17.

10. Roake, W.E., "The Systems $\mathrm{CaF}_{2}-\mathrm{LiF}$ and $\mathrm{CaF}_{2}-\mathrm{LiF}-\mathrm{MgF}_{2}$," Journal of the Electrochemical Soctety, Vol. 104, No. 11, Nov. 1957, pp. 661-662.

11. Lupis, C.H.P., Chemical Thermodynamics of Matertals, North-Holland, New York, 1983.

12. Rao, Y.K., "The Analysis and Calculation of Equilibria in Complex Metallurgical Systems," Metallurgical Transactions B, Vol. 14, No. 12, Dec. 1983, pp. 701-710

13. Kubaschewski, 0. and Alcock, C.B., Metallurgical Thermochemistry, Fifth Edition, Pergammon Press, New York, 1979.

14. Misra, A.K., "Thermodynamic Considerations for Corrosion of Metals in Thermal Energy Storage Systems Utilizing Fluorides as Phase Change Materials," submitted for publication in Corrosion Sctence.

15. Hong, K.C. and Kleppa, 0.J., "Thermochemistry of the Liquid Mixtures of Aluminium Fluoride with Alkali Fluorides and with Zinc Fluoride," Journal of Physiral Chemistry, Vol. 82, No. 2, Feb. 1978, pp. 176-182.

16. Hultgren, R., Selected Values of the Thermodynamic Properties of Binary Alloys, American Society for Metals, Metals Park, OH, 1973.

17. Lumsden, J., Thermodynamics of Molten Salt Mixtures, Academic Press, New York, 1966.

18. Laitinen, H.A., Ferguson, W.S., and Osteryoung, R.A., "Preparation of Pure Fused Lithium Chloride-Potassium Chloride Eutectic Solvent, " Journal of the Electrochemical Society, Vol. 104, No. 8, Aug. 1957, pp. 516-520.

19. Whittenberger, J.D. and Misra, A.K., "Identification of Salt-Alloy Combinations for Thermal Energy Storage Applications in Advanced Solar Dynamic Space Power Systems," Solar Engineering 1987, D.Y. Goswami, K. Watanabe, and H.M. Healey, eds., ASME, New York, 1987, pp. 356-365. 
TABLE I. - SUMMARY OF MELTING POINT AND HEAT OF FUSION MEASUREMENTS FOR FLUORIDES WITH PUBLISHED PHASE DIAGRAMS

\begin{tabular}{|c|c|c|c|}
\hline $\begin{array}{c}\text { Composition, } \\
\text { mol } \%\end{array}$ & $\begin{array}{l}\text { Melting } \\
\text { point, } \\
k\end{array}$ & $\begin{array}{l}\text { Heat of } \\
\text { fuston } \\
\text { per unit } \\
\text { mass, } \\
\mathrm{kJ} / \mathrm{g}\end{array}$ & $\begin{array}{l}\text { Heat of } \\
\text { fuston per } \\
\text { unit volume } \\
\text { of the melt, } \\
\mathrm{kJ} / \mathrm{cm}^{3}\end{array}$ \\
\hline $\mathrm{LIF}-30 \mathrm{MgF}{ }_{2}$ & 1001 & 0.52 & $c_{1.07}$ \\
\hline $\mathrm{NaF}-22 \mathrm{CaF}_{2}-13 \mathrm{MgF}_{2}$ & 1027 & .54 & $c_{1.17}$ \\
\hline $\mathrm{LIF}-20 \mathrm{CeF}_{3}$ & 1029 & .5 & $b_{1.58}$ \\
\hline $\mathrm{LIF}-19.5 \mathrm{CaF}_{2}$ & 1042 & .82 & $b_{1.7}$ \\
\hline $\mathrm{KF}-15 \mathrm{CaF}_{2}$ & 1053 & .44 & ${ }^{c_{0.88}}$ \\
\hline$K F-15 M g F_{2}$ & 1063 & .52 & $c_{1.03}$ \\
\hline $\mathrm{NaF}-20 \mathrm{MgF}_{2}-16 \mathrm{KF}$ & 1077 & .65 & $c_{1.31}$ \\
\hline $\mathrm{NaF}-32 \mathrm{CaF}_{2}$ & 1083 & .6 & $b_{1.4}$ \\
\hline $\mathrm{NaF}-23 \mathrm{MgF}_{2}$ & 1103 & .63 & $c_{1.3}$ \\
\hline Lif & 1121 & $a_{1.08}$ & $b_{1} .96$ \\
\hline$K F$ & 1129 & a. .486 & $b_{0.93}$ \\
\hline $\mathrm{NaF}-40 \mathrm{MgF}_{2}-2 \mathrm{CCaF}_{2}$ & 1187 & .59 & $c_{1.33}$ \\
\hline $\mathrm{CaF}_{2}-50 \mathrm{MgF}_{2}$ & 1250 & .54 & $c_{1.34}$ \\
\hline $\mathrm{NaF}-60 \mathrm{MgF} 2$ & 1269 & .71 & $c_{1.48}$ \\
\hline $\mathrm{NaF}$ & 1268 & a. 79 & $b_{1.54}$ \\
\hline$K F-69 M g F_{2}$ & 1279 & .77 & $c_{1.73}$ \\
\hline $\mathrm{NaMgF}_{3}$ & 1295 & .67 & $c_{1.48}$ \\
\hline $\mathrm{KF}-61 \mathrm{CaF}_{2}$ & 1328 & .45 & $c_{1.02}$ \\
\hline $\mathrm{KCaF}_{3}$ & 1343 & .46 & ${ }^{c} 1.01$ \\
\hline $\mathrm{KMgF}_{3}$ & 1345 & .71 & $c_{1.52}$ \\
\hline $\mathrm{MgF}_{2}$ & 1536 & a. 93 & $2.26^{b}$ \\
\hline
\end{tabular}

aobtained from Barin and Knacke's compilations (ref. 3).

bliquid density extrapolated from published data (refs. 4 to 6 ).

CLiquid density estimated by assuming ( 1 ) ideal solution behavior and (2) the molar volume of each component at its melting point does not change with temperature. 
TABLE II. - PARTIAL PHASE DIAGRAM DATA FOR THE LIF-MgF 2 SYSTEM

\begin{tabular}{|c|c|c|}
\hline $\begin{array}{c}\mathrm{MgF}_{2} \\
\text { concentration, } \\
\text { mol } \%\end{array}$ & $\begin{array}{c}\text { Solidus } \\
\text { temperature, } \\
K\end{array}$ & $\begin{array}{c}\text { Liquidus } \\
\text { temperature, } \\
K\end{array}$ \\
\hline $\begin{array}{l}5 \\
10 \\
15 \\
20 \\
25 \\
28 \\
30 \\
33 \\
35 \\
40 \\
50\end{array}$ & $\begin{array}{r}1063 \\
1041 \\
1014 \\
1003 \\
a_{1002} \\
a_{1001} \\
a_{1002} \\
a_{1001} \\
a_{1002} \\
a_{1002} \\
a_{1002}\end{array}$ & $\begin{array}{c}1103 \\
1088 \\
1063 \\
1043 \\
1020 \\
1001 \\
1002 \\
1003 \\
1073 \\
1143 \\
1253\end{array}$ \\
\hline
\end{tabular}

aEutectic temperature.

TABLE III. - COMPOSITION, MELTING POINT, AND HEAT OF FUSION FOR NEW EUTECTIC FLUORIDE SALTS

\begin{tabular}{|c|c|c|c|}
\hline $\begin{array}{l}\text { Composition, } \\
\text { mol } \%\end{array}$ & $\begin{array}{l}\text { Melting } \\
\text { point, } \\
k\end{array}$ & $\begin{array}{l}\text { Heat of } \\
\text { fusion } \\
\text { per unit } \\
\text { mass, } \\
\mathrm{kJ} / \mathrm{g}\end{array}$ & $\begin{array}{l}\text { Heat of } \\
\text { fusion per } \\
\text { unit volume } \\
\text { of the melt, } \\
\mathrm{kJ} / \mathrm{cm}^{3}\end{array}$ \\
\hline $\begin{array}{r}\text { Lif-19NaF } 19 \mathrm{MgF}_{2} \\
\left(\mathrm{LIF}-23 \mathrm{NaMgF}_{3}\right)\end{array}$ & 966 & 0.69 & ${ }^{\mathrm{a}} 1.39$ \\
\hline $\left.\begin{array}{r}L I F-13 K F-13 M g F \\
(L 1 F-15 K M g F \\
3\end{array}\right)$ & 1022 & .86 & ${ }_{1.67}$ \\
\hline $\mathrm{MgF}_{2}-40 \mathrm{CeF}_{3}$ & 1393 & .42 & a) 1.5 \\
\hline
\end{tabular}

aLiquid density estimated by assuming (1) ideal solution behavior and (2) the molar volume of each component at its melting point does not change with temperature. 
IABLE IV. - EXTENT OF UNDERCOOLING

FOR FLUORIDE SALTS

\begin{tabular}{|c|c|}
\hline $\begin{array}{c}\text { Composition, } \\
\text { mol } *\end{array}$ & $\begin{array}{c}\text { Degree of } \\
\text { undercooling, } \\
\text { K }\end{array}$ \\
\hline 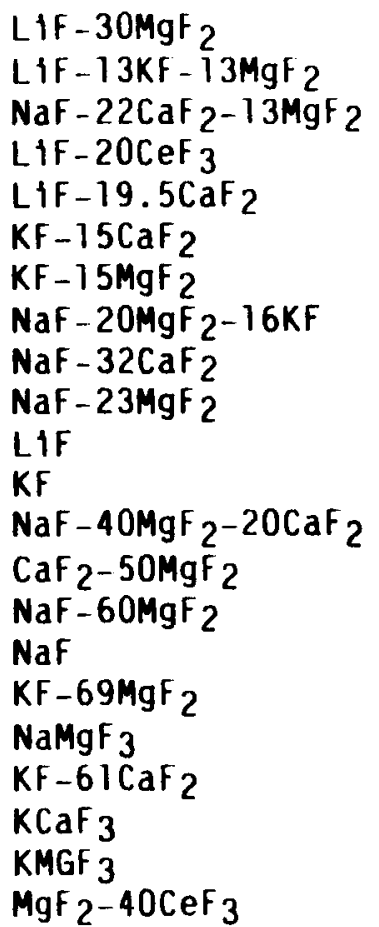 & $\begin{array}{c}0 \\
0 \\
15 \text { to } 30 \\
0 \\
2 \text { to } 3 \\
0 \\
0 \\
20 \text { to } 30 \\
30 \text { to } 40 \\
60 \text { to } 80 \\
0 \\
0 \\
40 \text { to } 60 \\
3 \text { to } 20 \\
70 \text { to } 80 \\
0 \\
20 \\
30 \text { to } 120 \\
30 \text { to } 40 \\
20 \text { to } 30 \\
20 \text { to } 30 \\
7 \text { to } 20\end{array}$ \\
\hline
\end{tabular}

aRange of values corresponds to the scatter in the data for different runs.

TABLE V. - ESTIMATED ACTIVITY COEFFICIENTS FOR DILUTE

SOLUTIONS OF Me ${ }_{x}{ }^{F}$

$$
\text { IN MF - Me } x_{x}{ }_{y}
$$

MELTS

\begin{tabular}{|c|c|c|}
\hline $\begin{array}{c}\text { Melt } \\
\text { system }\end{array}$ & Me $_{x} F_{y}$ & $\begin{array}{c}\text { Activity } \\
\text { coefficient } \\
\text { of Me } \text { M F }_{y}\end{array}$ \\
\hline $\mathrm{LiF}_{\mathrm{C}-\mathrm{CF}_{3}}$ & $\mathrm{CrF}_{3}$ & 0.001 \\
$\mathrm{NaF}-\mathrm{FeF}_{2}$ & $\mathrm{FeF}_{2}$ & .002 \\
$\mathrm{NaF}-\mathrm{NiF}_{2}$ & $\mathrm{NiF}_{2}$ & .01 \\
$\mathrm{NaF}-\mathrm{CrF}_{3}$ & $\mathrm{CrF}_{3}$ & .001 \\
\hline
\end{tabular}

TABLE VI. - NUMBER OF MOLES OF GASEOUS

REFRACTORY METAL FLUORIDE $\left(n_{g}\right)$

FORMED PER MOLE OF SALT FOR

REACTION OF THE METAL

WITH A NaF MELT

\begin{tabular}{|c|c|c|c|}
\hline $\begin{array}{c}\text { Gaseous } \\
\text { species }\end{array}$ & $\begin{array}{c}\text { Temperature, } \\
K\end{array}$ & $\begin{array}{c}\operatorname{LOG}\left(n_{\mathrm{g}}\right), \\
L=1.1\end{array}$ & $\begin{array}{c}\operatorname{LOG}\left(\mathrm{n}_{\mathrm{g}}\right), \\
L=2\end{array}$ \\
\hline $\mathrm{NbF}_{5}$ & 1100 & -7.5 & -7.3 \\
& 1300 & -6.4 & -6.2 \\
$\mathrm{MoF}_{6}$ & 1100 & -11.45 & -11.3 \\
& 1300 & -9.7 & -9.6 \\
$\mathrm{WF}_{6}$ & 1100 & -10.4 & -10.3 \\
& 1300 & -8.9 & -8.75 \\
\hline
\end{tabular}


TABLE VII. - SHEET ALLOYS PROPOSED FOR COMPATIBILITY STUDY

\begin{tabular}{|c|c|c|c|c|c|c|c|c|c|c|c|c|c|}
\hline \multirow[t]{2}{*}{ Alloy } & \multicolumn{13}{|c|}{ Composition, at $x$} \\
\hline & $\mathrm{Fe}$ & $\mathrm{Cr}$ & $\mathbf{N i}$ & Co & Mn & Si & Mo & Nb & $\mathrm{Ta}$ & $W$ & Al & C & Other \\
\hline \multicolumn{14}{|c|}{ Cobalt base } \\
\hline $\begin{array}{l}\text { Haynes } 188 \\
\text { H25 }\end{array}$ & $\begin{array}{l}1.7 \\
3.4\end{array}$ & $\begin{array}{l}28.2 \\
24.1\end{array}$ & $\begin{array}{l}24.1 \\
10.7\end{array}$ & $\begin{array}{l}38.2 \\
52.5\end{array}$ & $\begin{array}{l}0.7 \\
1.7\end{array}$ & $\begin{array}{l}1.6 \\
2.2\end{array}$ & ---- & --- & --- & $\begin{array}{l}5.2 \\
1.1\end{array}$ & --- & $\begin{array}{r}0.4 \\
.4\end{array}$ & $0.05 \mathrm{La}$ \\
\hline \multicolumn{14}{|c|}{ Nickel base } \\
\hline $\begin{array}{l}\text { Hastelloy-B } \\
\text { False } N \\
\text { Hastelloy-N } \\
\text { Hastelloy-S } \\
\text { Hastelloy-X } \\
\text { Inconel } 600 \\
\text { Inconel } 702 \\
\text { Inconel } 718 \\
\text { Nimonic } 75 \\
\text { NI-200 }\end{array}$ & $\begin{array}{r}5.9 \\
.5 \\
5.1 \\
0.9 \\
22.1 \\
9.7 \\
.5 \\
19.5 \\
.5 \\
-.--\end{array}$ & $\begin{array}{r}0.4 \\
19.8 \\
8.3 \\
19.6 \\
25.9 \\
18.9 \\
19.4 \\
22.9 \\
24.4 \\
\ldots . .\end{array}$ & $\begin{array}{l}70.5 \\
67.7 \\
72.9 \\
66.1 \\
41.5 \\
69.9 \\
73 . \\
48.9 \\
72 . \\
99.6\end{array}$ & \begin{tabular}{c}
0.8 \\
$\cdots$ \\
\hdashline- \\
\hdashline 1.9 \\
\hdashline- \\
$-\cdots$ \\
$-\cdots$ \\
$-\cdots$
\end{tabular} & $\begin{array}{l}0.8 \\
0.6 \\
.6 \\
.6 \\
.6 \\
.6 \\
.1 \\
.05 \\
.4 \\
.2\end{array}$ & $\begin{array}{l}0.9 \\
0.9 \\
1.1 \\
1.1 \\
1.2 \\
.2 \\
.2 \\
1.6 \\
1.6 \\
-.-\end{array}$ & \begin{tabular}{r}
19.5 \\
9.6 \\
11.1 \\
10. \\
5.2 \\
.--- \\
\hdashline 1.6 \\
..-- \\
..--
\end{tabular} & $\begin{array}{l}--- \\
---. \\
--- \\
--- \\
--- \\
--- \\
--. \\
2.6 \\
-\cdots \\
--.\end{array}$ & $\begin{array}{l}---- \\
---- \\
---- \\
--- \\
--- \\
--- \\
-\cdots \\
--- \\
--- \\
---\end{array}$ & 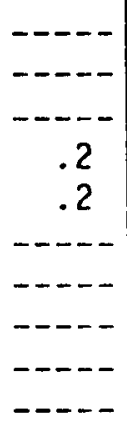 & $\begin{array}{r}1 . \\
0.7 \\
.5 \\
.7 \\
.9 \\
-.- \\
5.9 \\
1.3 \\
.6 \\
-.-\end{array}$ & $\begin{array}{r}0.3 \\
.7 \\
.3 \\
1.0 \\
.5 \\
.5 \\
.5 \\
.5 \\
.05 \\
. . .\end{array}$ & $\begin{array}{l}0.24 \mathrm{~V} \\
.24 \mathrm{Ti} \\
.511 \\
1.2 \mathrm{Ti} \\
- \\
-\end{array}$ \\
\hline \multicolumn{14}{|c|}{ Iron base } \\
\hline $\begin{array}{l}19-9 D L \\
304 \\
310 \\
316 \\
347 \\
\text { A286 (CW } 50 \\
\quad \text { percent) } \\
\text { Armco } 18 \text { SRa } \\
\text { Inconel } 800 \\
\text { Mild steel } \\
\text { N-155 } \\
\text { Nitronic } 40 \\
\text { PHI4-8Mo } \\
\text { RA 330 }\end{array}$ & $\begin{array}{l}64.8 \\
68.5 \\
49.4 \\
62.2 \\
65.3 \\
53 . \\
\\
72 . \\
45.1 \\
98.6 \\
31.5 \\
59.3 \\
70.7 \\
43.8\end{array}$ & $\begin{array}{l}20.4 \\
19.8 \\
27.4 \\
20 . \\
21.4 \\
17.1 \\
19.1 \\
22.6 \\
---- \\
25.1 \\
23.1 \\
16.4 \\
21.9\end{array}$ & $\begin{array}{r}10 \\
8.6 \\
19.1 \\
13.5 \\
10.5 \\
22.5 \\
1.8 \\
29.8 \\
---- \\
18.7 \\
7.4 \\
8.3 \\
30 .\end{array}$ & $\begin{array}{l}-\cdots \\
-\cdots \\
-\cdots \\
-\cdots \\
-\cdots \\
-\cdots \\
-\cdots \\
-\cdots \\
18.6 \\
-\cdots \\
-\cdots\end{array}$ & $\begin{array}{l}1 \\
1.3 \\
1.2 \\
1.4 \\
1 . \\
1 . \\
.1 \\
.6 \\
.5 \\
1 . \\
7.1 \\
-1.4\end{array}$ & $\begin{array}{l}1.6 \\
1.6 \\
1.4 \\
1 . \\
1.4 \\
1.6 \\
2.7 \\
1 . \\
-1.6 \\
1.7 \\
--- \\
2.5\end{array}$ & 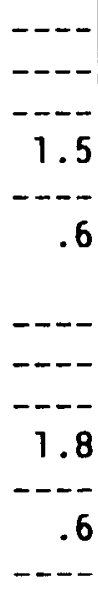 & $\begin{array}{r}-\cdots \\
-\cdots \\
\cdots \\
-\cdots \\
-\cdots \\
-\cdots \\
-\cdots \\
. .5 \\
-\cdots \\
1.3 \\
-\cdots\end{array}$ & $\begin{array}{c}0.3 \\
--- \\
--- \\
-\cdots \\
--- \\
--- \\
-\cdots \\
-\cdots \\
-\cdots \\
--- \\
--- \\
--- \\
---\end{array}$ & 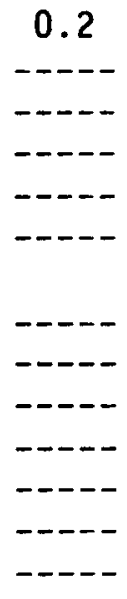 & $\begin{array}{l}--- \\
-.- \\
--- \\
--- \\
-- \\
.4 \\
3.6 \\
--- \\
--- \\
--- \\
-- \\
2.5 \\
---\end{array}$ & $\begin{array}{r}1.4 \\
.2 \\
1.1 \\
.4 \\
.4 \\
.4 \\
\\
.2 \\
.5 \\
.9 \\
.7 \\
.4 \\
.2 \\
.4\end{array}$ & \begin{tabular}{c}
$0.3 \mathrm{TI}$ \\
$.5 \mathrm{TH}$ \\
$3.1 \mathrm{TH}$ \\
$.6 \mathrm{TH}$ \\
$.4 \mathrm{CU}$ \\
$.60 \mathrm{~N}$ \\
$1.2 \mathrm{~N}$ \\
\\
\hdashline
\end{tabular} \\
\hline \multicolumn{14}{|c|}{ Refractory metal } \\
\hline $\begin{array}{l}\text { Mo } \\
\text { Nb- } 1<r \\
\mathrm{Ta} \\
W\end{array}$ & $\ldots$ & $\ldots$ & $\begin{array}{l}\ldots- \\
\cdots- \\
\cdots- \\
-\ldots\end{array}$ & $\begin{array}{l}\cdots- \\
\cdots \\
\cdots- \\
-\cdots\end{array}$ & $\begin{array}{l}-\cdots \\
-\cdots \\
-\cdots \\
-\cdots\end{array}$ & $\begin{array}{l}--- \\
--- \\
--- \\
---\end{array}$ & $\begin{array}{l}99.8 \\
--- \\
--- \\
---\end{array}$ & $\begin{array}{r}-.-. \\
98.9 \\
.-2\end{array}$ & -.-- & 99.85 & $\begin{array}{l}-- \\
-- \\
--- \\
---\end{array}$ & $\begin{array}{r}0.2 \\
-.15 \\
.15 \\
.15\end{array}$ & $\begin{array}{r}1.1 \mathrm{Zr} \\
.13 \mathrm{~N}\end{array}$ \\
\hline
\end{tabular}

aferritic alloy; all other fron base alloys are austenitic. 
IABLE VIII. - SUMMARY OF ATTACK OF VARIOUS ALLOYS CAUSEO BY EXPOSURE TO EUTECTIC FLUORIDE SALT MIXTURES IN ALUMINA

CRUCIBLES UNDER $1 \mathrm{~atm}$ OF ARGON

\begin{tabular}{|c|c|c|c|c|c|c|}
\hline \multirow{3}{*}{$\begin{array}{l}\text { Composition, at } x \\
\text { Melting point, } k \\
\text { Exposure conditions }\end{array}$} & \multicolumn{2}{|c|}{$\begin{array}{c}\mathrm{LF}-19.5 \mathrm{CaF}_{2} \\
1039 \\
100 \mathrm{hr}-1070 \mathrm{~K}\end{array}$} & \multicolumn{2}{|c|}{$\begin{array}{c}\mathrm{LIF}-19.5 \mathrm{CaF}_{2} \\
1039 \\
500 \mathrm{hr}-1070 \mathrm{k}\end{array}$} & \multicolumn{2}{|c|}{$\begin{array}{c}\mathrm{NaF}-27 \mathrm{CaF}_{2}-36 \mathrm{MgF} 2 \\
1178 \\
100 \mathrm{hr}-1203 \mathrm{~K}\end{array}$} \\
\hline & \multicolumn{6}{|c|}{ Depth of corrosive attack, $\mu \mathrm{m}$} \\
\hline & General & $\begin{array}{l}\text { Grain } \\
\text { boundary }\end{array}$ & General & $\begin{array}{l}\text { Grain } \\
\text { boundary }\end{array}$ & General & $\begin{array}{l}\text { Graln } \\
\text { boundary }\end{array}$ \\
\hline \multicolumn{7}{|l|}{ Co-base } \\
\hline $\begin{array}{l}H-25 \\
H S-188\end{array}$ & $\begin{array}{l}-- \\
--\end{array}$ & $\begin{array}{l}12 \\
-5 \\
47\end{array}$ & $\begin{array}{l}-- \\
--\end{array}$ & $\begin{array}{r}95 \\
70 \\
105\end{array}$ & $\begin{array}{l}-- \\
--\end{array}$ & $\begin{array}{r}8 \\
\text { a } 25 \\
18\end{array}$ \\
\hline \multicolumn{7}{|l|}{ Fe-base } \\
\hline 304 & $\overline{1}$ & 20 & - & 185 & -- & $b_{5}$ \\
\hline 310 & $\begin{array}{l}17 \\
--\end{array}$ & -- & $\begin{array}{l}-- \\
--\end{array}$ & $\begin{array}{l}130 \\
---\end{array}$ & -- & $\begin{array}{r}5 \\
\mathrm{a}_{10}\end{array}$ \\
\hline \multirow[t]{2}{*}{316} & -- & 45 & - & 165 & -- & 10 \\
\hline & -- & -- & -- & -- & -- & a) 5 \\
\hline 347 & -- & -- & -- & --- & -- & $b_{8}$ \\
\hline A286 & 43 & -- & -- & -- & -- & 10 \\
\hline Armco $18 S R$ & -- & -- & -- & -- & -- & 38 \\
\hline Incoloy 800 & -- & 45 & -- & --- & 30 & -- \\
\hline \multirow[t]{2}{*}{ Mild steel } & -- & -- & -- & 155 & 12 & -- \\
\hline & -- & -- & -- & -- & -- & $a_{--}$ \\
\hline PHI 4-8 & 14 & -- & -- & -- & 10 & -- \\
\hline$R A-330$ & -- & - & -- & 270 & -- & 20 \\
\hline \multicolumn{7}{|l|}{ N1-base } \\
\hline \multirow[t]{2}{*}{ Hastelloy 8} & 8 & -- & 30 & --- & -- & -- \\
\hline & -- & -- & 20 & --- & -- & -- \\
\hline \multirow[t]{2}{*}{ Hastelloy $\mathrm{N}$} & -- & 20 & 15 & 15 & -- & 15 \\
\hline & -- & -- & -- & -- & -- & $a_{25}$ \\
\hline False N & -- & 27 & -- & 135 & -- & - \\
\hline Hastelloy S & -- & -- & 90 & -- & 0 & 10 \\
\hline Hastelloy $x$ & -- & 45 & - & 140 & -- & $b_{38}$ \\
\hline Inconel 600 & 13 & 34 & 90 & 30 & -- & 13 \\
\hline Inconel 702 & 15 & 60 & -- & --- & -- & - \\
\hline \multirow[t]{2}{*}{ Inconel 718} & 13 & 24 & 45 & 120 & -- & 8 \\
\hline & -- & -- & -- & -- & -- & a 50 \\
\hline \multirow{2}{*}{$N\}-200$} & -- & -- & -- & -- & 8 & -- \\
\hline & -- & -- & -- & -- & 18 & -- \\
\hline Nimonic 75 & -- & -- & 30 & 135 & -- & -- \\
\hline \multicolumn{7}{|l|}{ Refractory } \\
\hline Mo & -- & -- & -- & -- & - & -- \\
\hline $\mathrm{Nb}-1 \mathrm{Zr}$ & -- & -- & -- & --- & -- & -- \\
\hline \multirow{2}{*}{$\mathrm{Ta}$} & -- & -- & -- & --- & 60 & -- \\
\hline & -- & -- & -- & --- & 25 & $\mathrm{a}_{--}$ \\
\hline w & -- & -- & -- & -- & -- & -- \\
\hline
\end{tabular}

a Exposures conducted with a piece of quartz in the crucible.

bNo difference between exposures with/without quartz in crucible. 


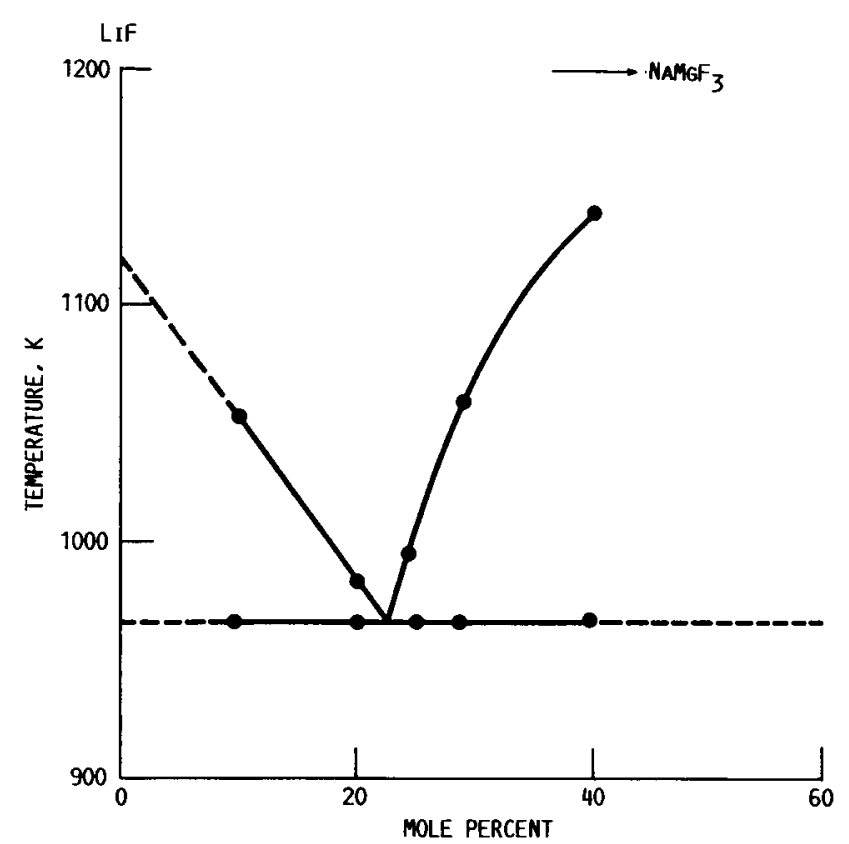

FIGURE 1. - PARTIAL PHASE DIAGRAM FOR THE LIF-NAMGF 3 SYSTEM.

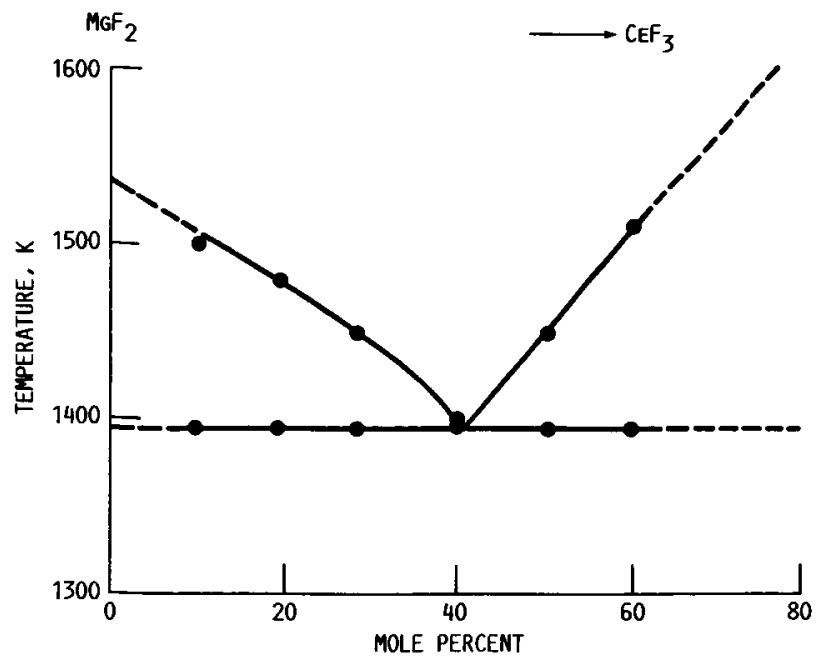

figure 3. - PARTIAL PHASE diagraM fOR THE $\mathrm{MGF}_{2}-\mathrm{CEF}_{3}$ SYSTEM.

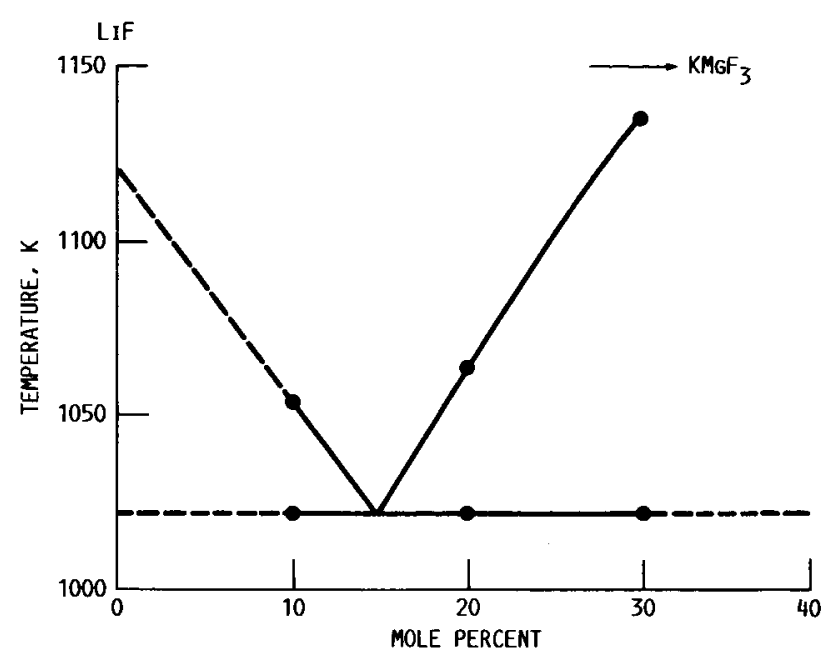

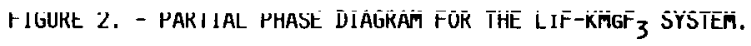

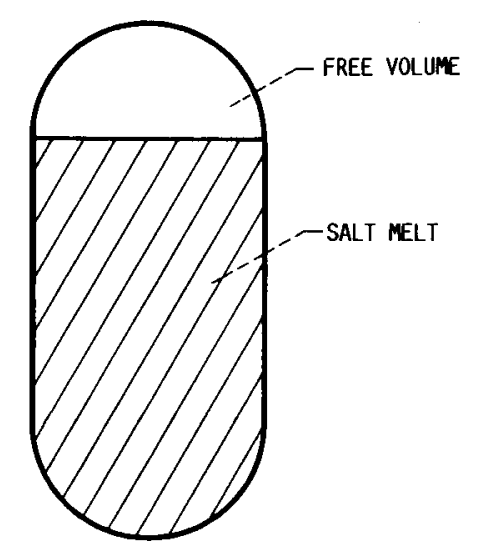

FIGURE 4. - SCHEMATIC OF A THERMAL ENERGY STORAGE SALT CONTAINER. 


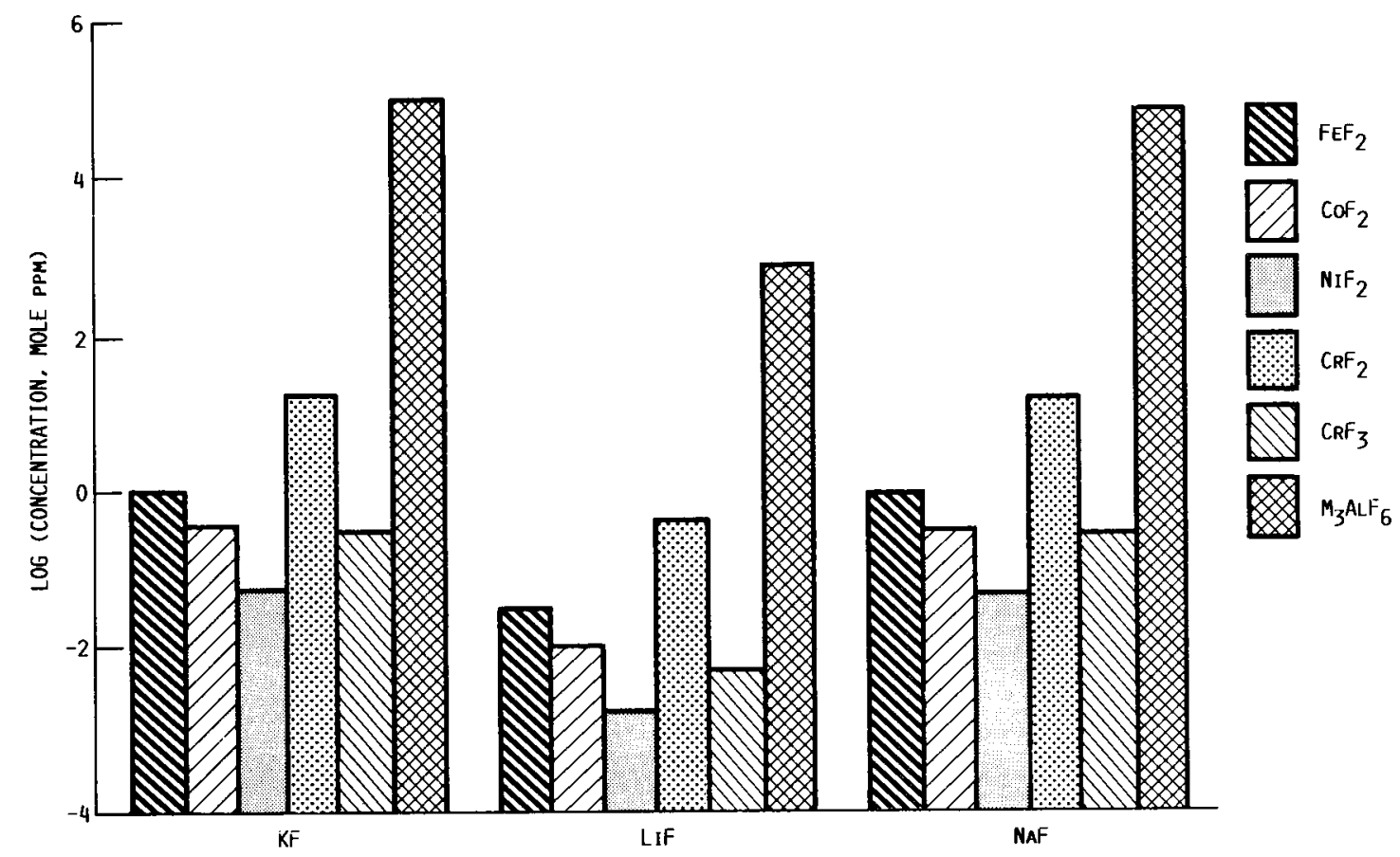

FIGURE 5. - CALCULATED EQUILIBRIUM CONCENTRATION OF MEX $F_{Y}\left(M=F E, N I, C O, C_{R}\right.$, OR AL) AFTER CORROSION IN ONE MOLE OF ALKALI FLUORIDE MELT AT $1100 \mathrm{~K}$ IN AN INERT ATMOSPHERE (IDEAL SOLUTION BEHAVIOR IN THE MELT ASSUMED).

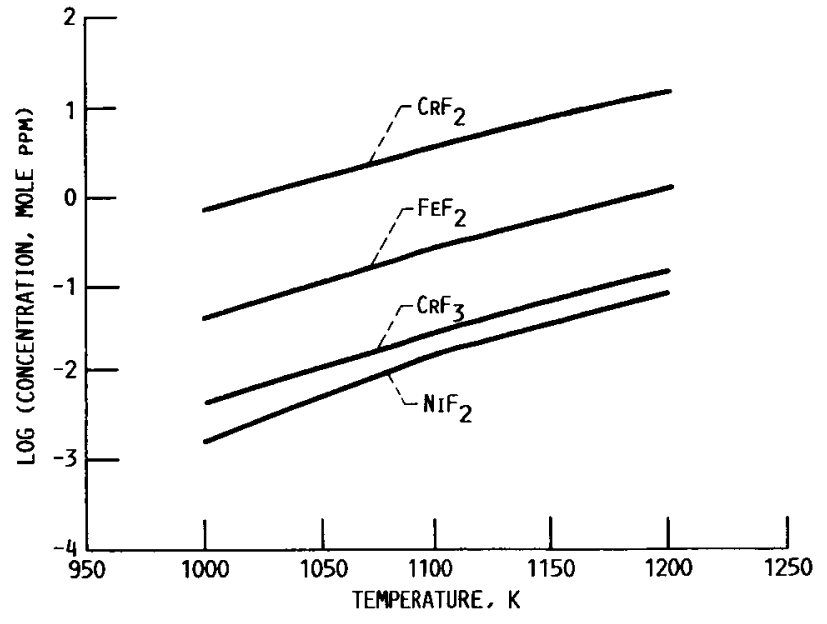

FIGURE 6. - EQUILIBRIUM CONCENTRATION OF ME $F_{Y}$, CALCULATED WITH AN ACTIVITY COEFFICIENT OF 0.001, AFTER CORROSION IN ONE MOLE OF LIF MELT UNDER AN INERT ATMOSPHERE.

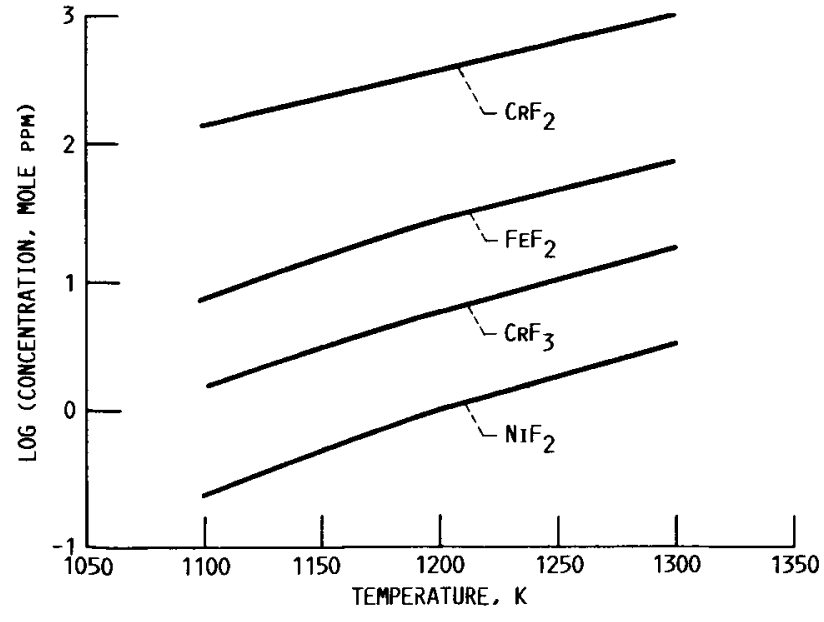

FIGURE 7. - EQUILIBRIUM CONCENTRATION OF ME $F_{y}$. CALCULATED WITH ESTIMATED ACTIVITY COEFFICIENTS, AFTER CORROSION IN ONE MOLE OF NAF MELT UNDER AN INERT ATMOSPHERE. 

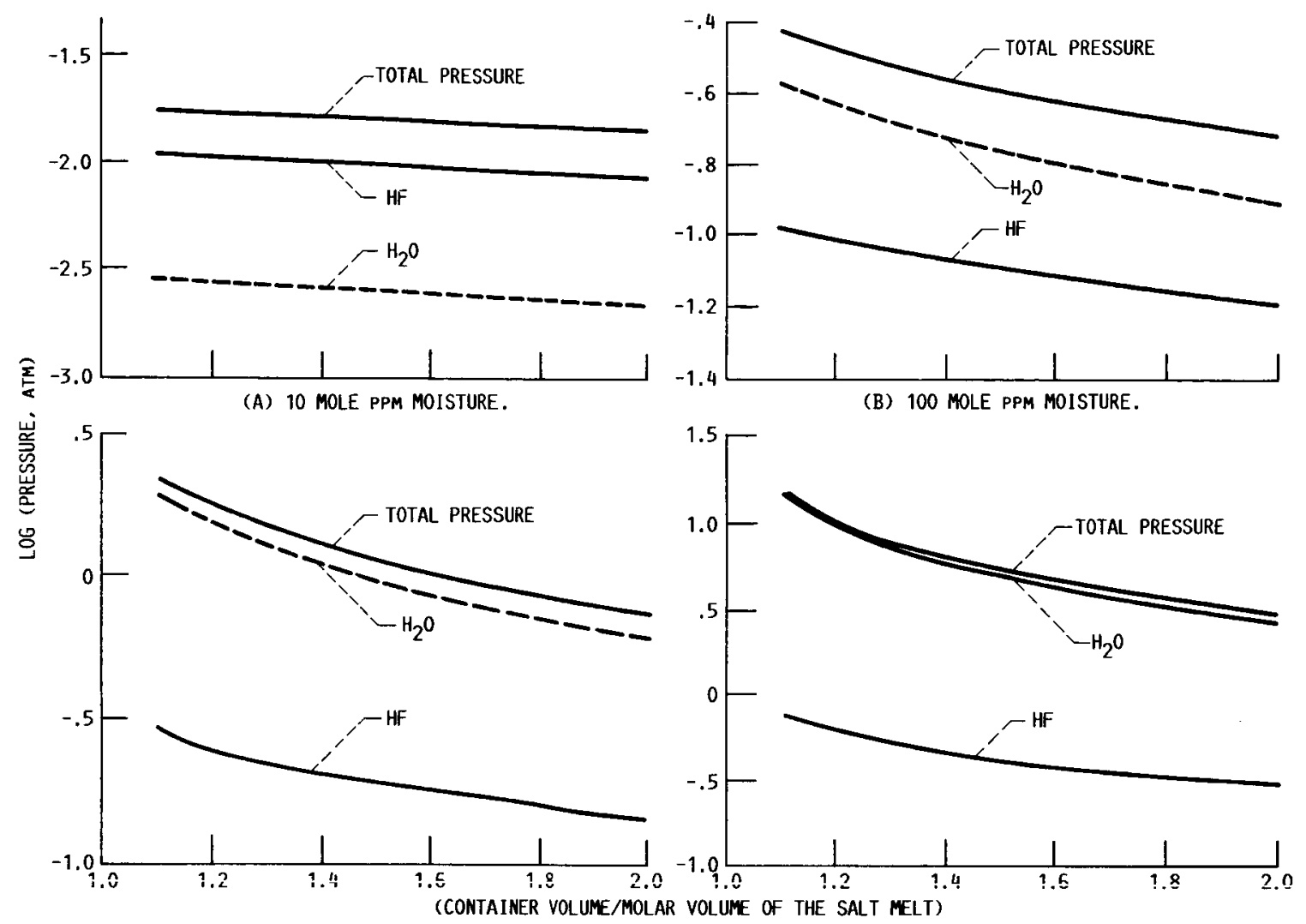

(C) 300 MOLE PPM MOISTURE.

(D) 1000 MOLE PPM MOISTURE.

FiguRE 8. - PARTIAL PRESSURES OF HF AND H2 0 AND tOTAL PRESSURE INSIDE THE CONTAINER FOR A NAF MELT AT $1100 \mathrm{~K}$ AS A FUNCTION OF MOISTURE CONTENT AND L RATIO.

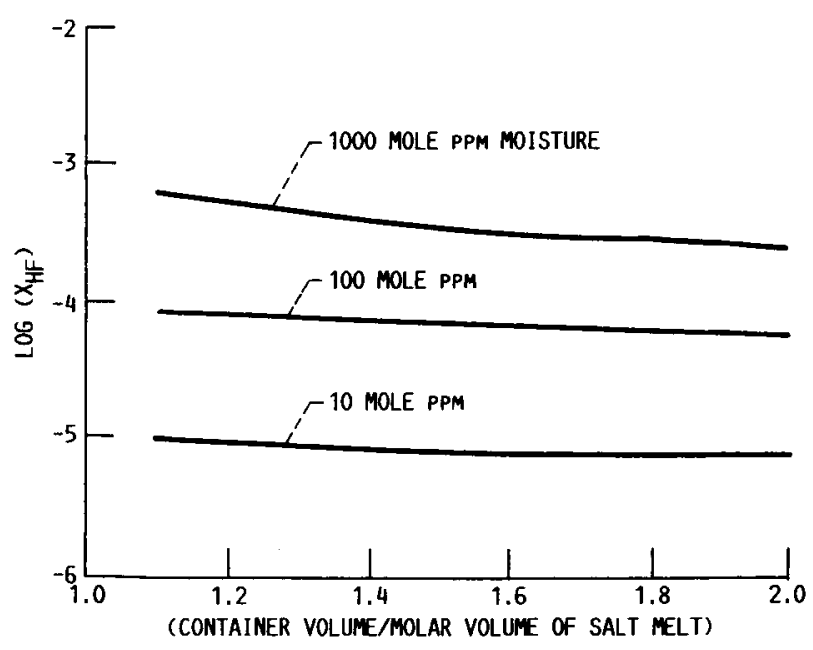

FIGURE 9. - MOLE FRACTION OF DISSOLVED HF $\left(X_{H F}\right)$ IN THE MELT AS A FUNCTION OF MOISTURE FOR A NAF MELT AT $1100 \mathrm{~K}$.

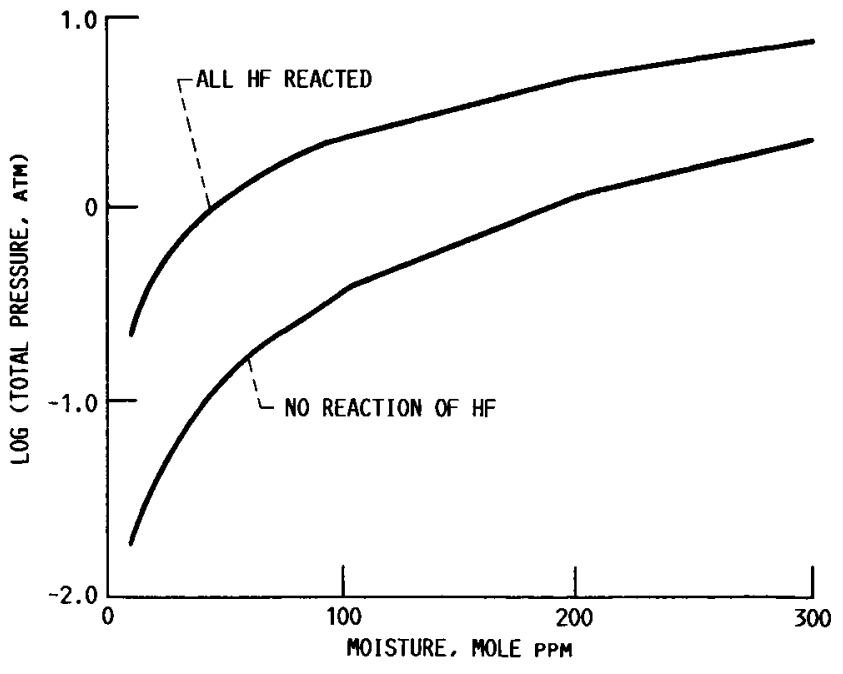

FIGURE 10. - EFFECT OF THE REACTION OF DISSOLVED HF WITH THE CONTAINER MATERIAL ON THE TOTAL PRESSURE GENERATED INSIDE THE CONTAINER. 

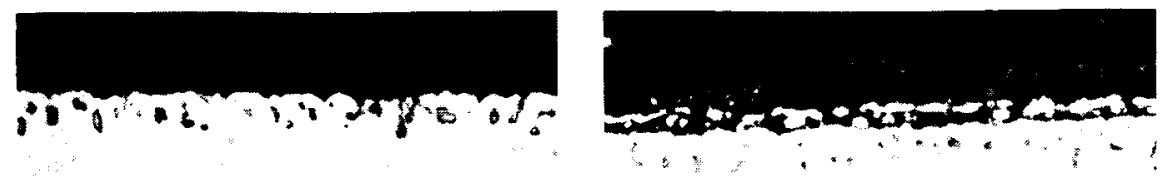

$20 \mu \mathrm{M}$

(A) HASTELLOY B.

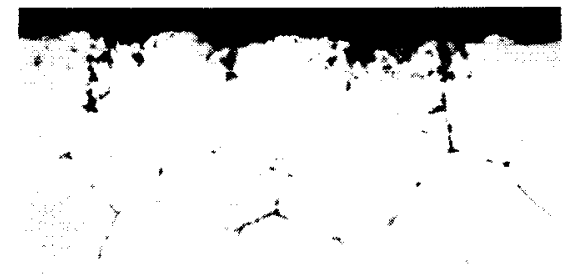

$$
20 \mu \mathrm{M}
$$

(C) HS- 188 .
$20 \mu \mathrm{m}$

(B) PH14-8.
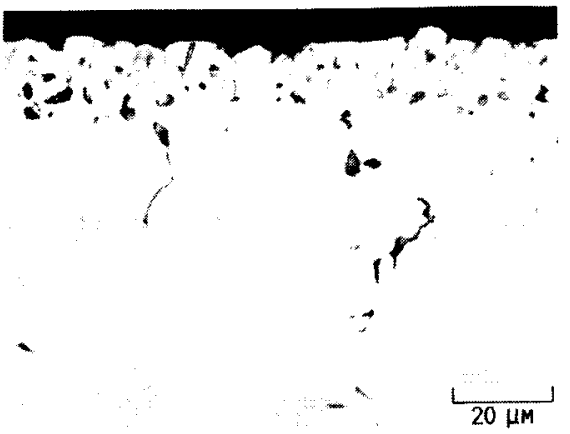

(D) 702 .

FIGURE 11. - PHOTOMICROGRAPHS OF SPECIMENS AFTER 100 HR EXPOSURES TO LIF-19.5CAF 2 AT $1070 \mathrm{~K}$ IN ALUMINA CRUCIBLES UNDER 1 ATMOSPHERE OF ARGON.

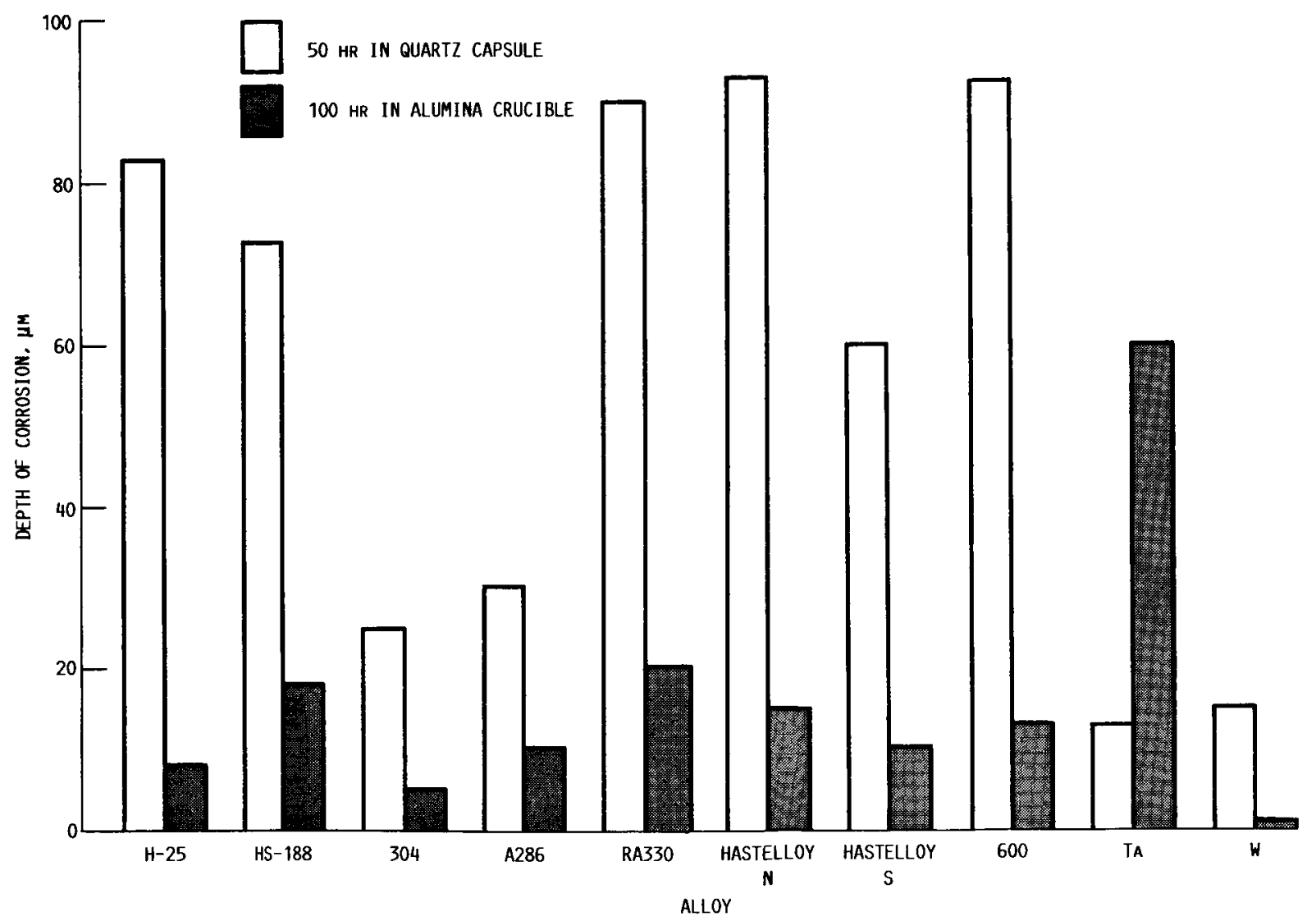

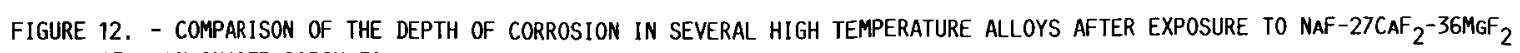
AT $1203 \mathrm{~K}$ IN QUARTZ CAPSULES AND ALUMINA CRUCIBLES. 


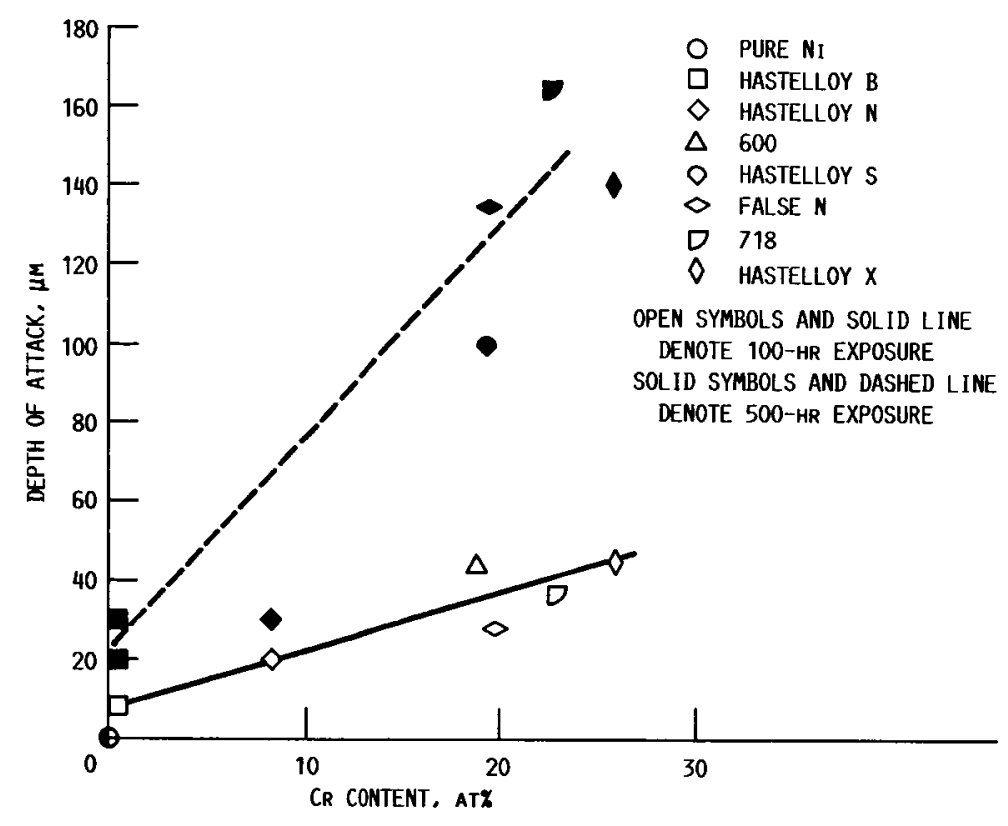

FiguRE 13. - DEPTH OF MICROSTRUCTURAL DAMAGE AS A FUNCTION OF CR LEVEL FOR ALLOYS EXPOSED TO LIF-19.5CAF 2 AT $1070 \mathrm{~K}$ IN ALUMINA CRUCIBLES UNDER 1 ATMOSPHERE OF ARGON.
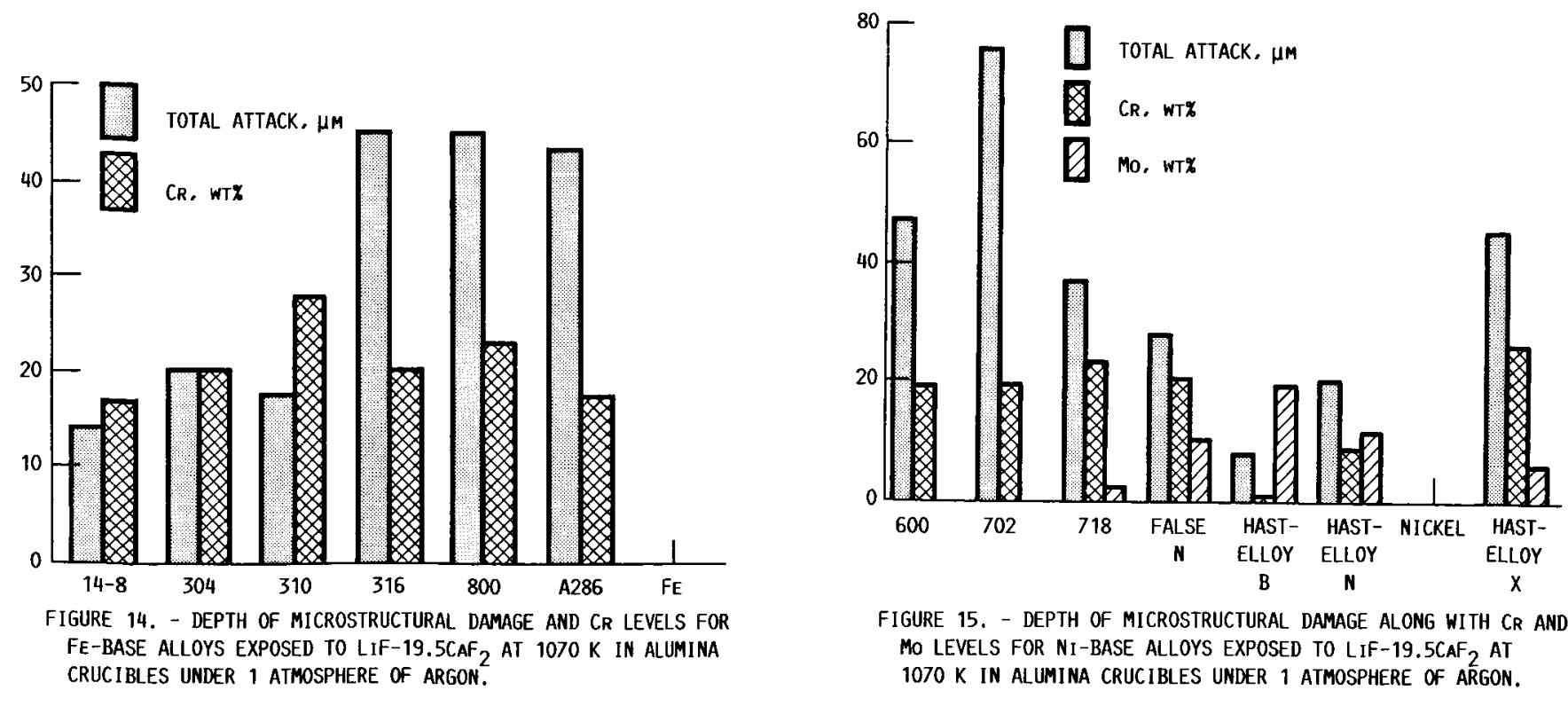

FIGURE 15. - DEPTH OF MICROSTRUCTURAL DAMAGE ALONG WITH $C_{R}$ AND MO LEVELS FOR NI-BASE ALLOYS EXPOSED TO LIF-19.5CAF 2 AT $1070 \mathrm{~K}$ IN ALUMINA CRUCIBLES UNDER 1 ATMOSPHERE OF ARGON. 


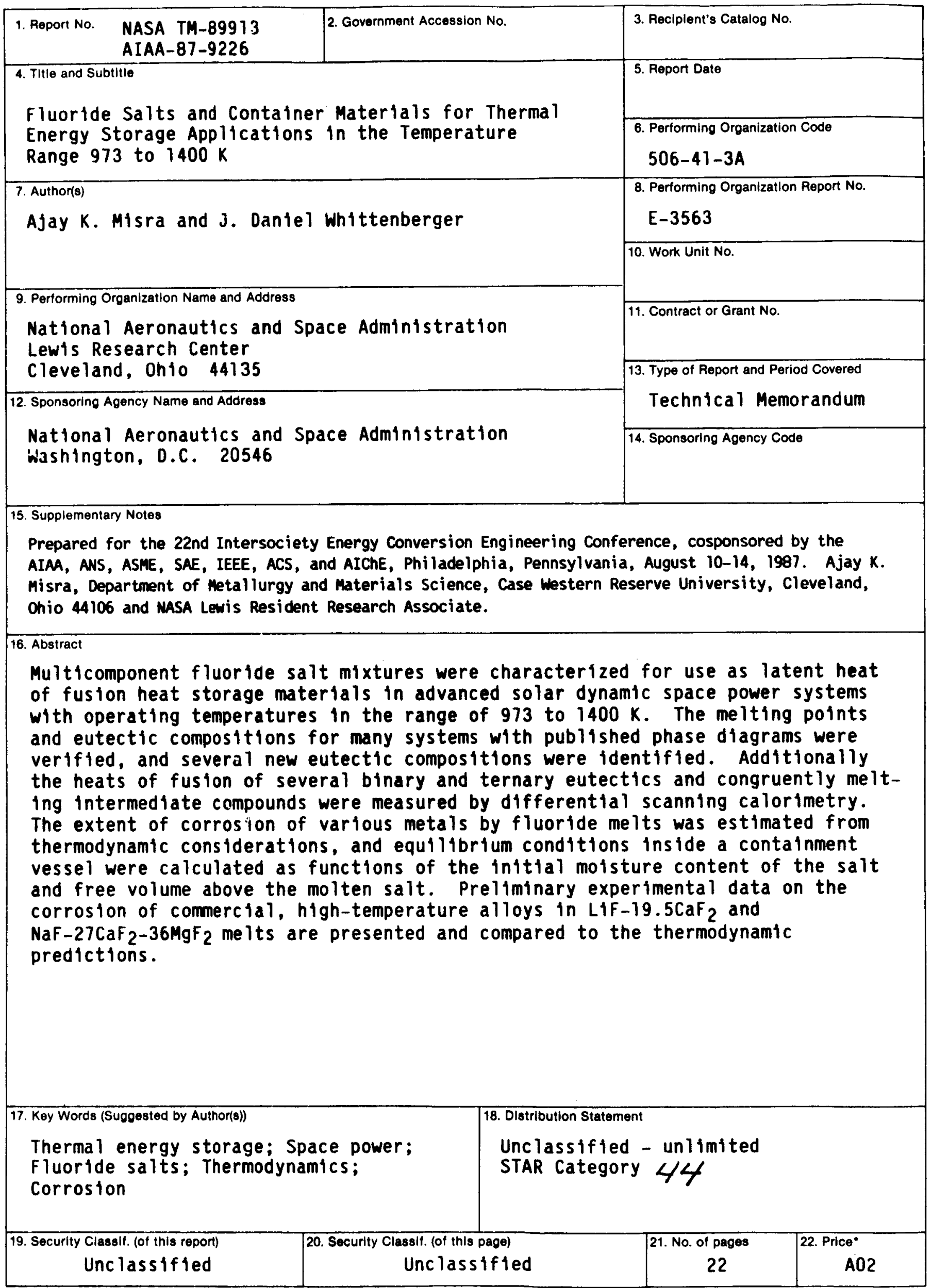

*For sele by the Natlonal Technlcal Information Service, Springfield, Virginia 22161 